University of Nebraska - Lincoln

DigitalCommons@University of Nebraska - Lincoln

8-10-2010

Study of Heart and Renal Protection (SHARP): Randomized trial to assess the effects of lowering low-density lipoprotein cholesterol among 9,438 patients with chronic kidney disease 


\title{
Study of Heart and Renal Protection (SHARP): Randomized trial to assess the effects of lowering low-density lipoprotein cholesterol among 9,438 patients with chronic kidney disease
}

\author{
SHARP Collaborative Group
}

\begin{abstract}
Background Lowering low-density lipoprotein (LDL) cholesterol with statin therapy has been shown to reduce the incidence of atherosclerotic events in many types of patient, but it remains uncertain whether it is of net benefit among people with chronic kidney disease (CKD).
\end{abstract}

Methods Patients with advanced CKD (blood creatinine $\geq 1.7 \mathrm{mg} / \mathrm{dL}[\geq 150 \mu \mathrm{mol} / \mathrm{L}]$ in men or $\geq 1.5 \mathrm{mg} / \mathrm{dL}[\geq 130 \mu \mathrm{mol} / \mathrm{L}]$ in women) with no known history of myocardial infarction or coronary revascularization were randomized in a ratio of 4:4:1 to ezetimibe $10 \mathrm{mg}$ plus simvastatin $20 \mathrm{mg}$ daily versus matching placebo versus simvastatin $20 \mathrm{mg}$ daily (with the latter arm rerandomized at 1 year to ezetimibe $10 \mathrm{mg}$ plus simvastatin $20 \mathrm{mg}$ daily vs placebo). The key outcome will be major atherosclerotic events, defined as the combination of myocardial infarction, coronary death, ischemic stroke, or any revascularization procedure.

Results A total of 9,438 CKD patients were randomized, of whom 3,056 were on dialysis. Mean age was 61 years, two thirds were male, one fifth had diabetes mellitus, and one sixth had vascular disease. Compared with either placebo or simvastatin alone, allocation to ezetimibe plus simvastatin was not associated with any excess of myopathy, hepatic toxicity, or biliary complications during the first year of follow-up. Compared with placebo, allocation to ezetimibe $10 \mathrm{mg}$ plus simvastatin $20 \mathrm{mg}$ daily yielded average LDL cholesterol differences of $43 \mathrm{mg} / \mathrm{dL}(1.10 \mathrm{mmol} / \mathrm{L})$ at 1 year and $33 \mathrm{mg} / \mathrm{dL}$ $(0.85 \mathrm{mmol} / \mathrm{L})$ at 2.5 years. Follow-up is scheduled to continue until August 2010, when all patients will have been followed for at least 4 years.

Conclusions SHARP should provide evidence about the efficacy and safety of lowering LDL cholesterol with the combination of ezetimibe and simvastatin among a wide range of patients with CKD. (Am Heart J 2010;160:785-794.e10.)

\section{Background}

Observational studies in unselected populations have shown that there is a continuous positive relationship between coronary heart disease (CHD) risk and blood low-density lipoprotein (LDL) cholesterol that extends well below the range seen in Western populations. ${ }^{1,2} \mathrm{~A}$ meta-analysis of randomized trials has shown that statin therapy reduces the incidence of major coronary events

ClinicalTrials.gov identifier NCTO0125593, ISRCTN number 54137607.

Submitted July 21, 2010; accepted August 10, 2010.

Reprint requests: SHARP International Coordinating Centre, Clinical Trial Service Unit and Epidemiological Studies Unit (CTSU), Richard Doll Bldg, Old Road Campus, Roosevelt Dr, Oxford OX3 $7 L F$, United Kingdom.

E-mail: sharp@ctsu.ox.ac.uk

0002-8703/\$ - see front matter

(C) 2010, Mosby, Inc. All rights reserved.

doi:10.1016/i.ahj.2010.08.012 (nonfatal myocardial infarction [MI] or CHD mortality), of ischemic strokes, and of coronary revascularizations by about one fifth for every $1-\mathrm{mmol} / \mathrm{L}(39-\mathrm{mg} / \mathrm{dL})$ reduction in LDL cholesterol, while producing no benefit on hemorrhagic stroke or on vascular causes of death other than CHD. ${ }^{3,4}$ Among people without known chronic kidney disease (CKD), in whom estimated glomerular filtration rate (eGFR) is typically greater than about $60 \mathrm{~mL} / \mathrm{min} / 1.73 \mathrm{~m}^{2}$, the proportional reduction in the risk of a major vascular event (ie, major coronary event, stroke, or coronary revascularization) appears to be independent of renal function. ${ }^{4}$

The etiology of cardiovascular disease among patients with preserved renal function (or only minor renal dysfunction) is typically atherosclerotic, but a quite distinct type of cardiovascular pathology is observed once GFR falls to less than about $30 \mathrm{~mL} / \mathrm{min} / 1.73 \mathrm{~m}^{2}$. Several mechanisms resulting from renal metabolic 
dysregulation (eg, arterial calcification, left ventricular hypertrophy, and sympathetic overactivity) are believed to contribute to an increased risk of cardiac arrhythmia and heart failure. ${ }^{5}$ A key question, therefore, is whether reducing LDL cholesterol can prevent the types of vascular events (notably sudden cardiac death) that predominate as renal impairment progresses. Two randomized trials have examined the effects of lowering LDL cholesterol with statin therapy among dialysis patients. In the $4 \mathrm{D}$ randomized trial of atorvastatin $20 \mathrm{mg}$ daily versus placebo among 1,255 hemodialysis patients with type 2 diabetes, lowering LDL cholesterol by an average of $39 \mathrm{mg} / \mathrm{dL}(1.0 \mathrm{mmol} / \mathrm{L})$ for a median of 4 years yielded a nonsignificant $8 \%$ reduction in the prespecified primary outcome of cardiac death, nonfatal MI, or stroke. ${ }^{6}$ Similarly, in the AURORA randomized trial of rosuvastatin $10 \mathrm{mg}$ daily versus placebo among 2,776 hemodialysis patients, lowering LDL cholesterol by an average of $39 \mathrm{mg} / \mathrm{dL}(1.0 \mathrm{mmol} / \mathrm{L})$ for 4 years yielded a nonsignificant $4 \%$ reduction in the primary outcome of cardiovascular death, nonfatal MI, or stroke. ${ }^{7}$ A high proportion of cardiac deaths in these trials was not attributable to CHD, and there was no evidence in either trial of a reduction in the risk of such deaths. ${ }^{6,7}$ However, although lowering LDL cholesterol with statin therapy among patients with end-stage renal failure did not produce statistically significant reductions in the primary outcomes in these trials, there were promising proportional reductions of $18 \%$ (relative risk $0.82,95 \%$ CI 0.68 $0.99, P=.03$ ) in major cardiac events in the $4 \mathrm{D}$ trial $^{6}$ and of $16 \%$ (relative risk $0.84,95 \%$ CI $0.64-1.11, P=.2$ ) in nonfatal MI in the AURORA trial. ${ }^{7}$ These findings raise the possibility of small, but worthwhile, proportional benefits on atherosclerotic outcomes among dialysis patients and of larger proportional benefits among those with less severe renal impairment (in whom a higher proportion of events is likely to be atherosclerotic).

The Study of Heart and Renal Protection (SHARP) aims to address these uncertainties by assessing the effects of reducing LDL cholesterol by an average of about $1 \mathrm{mmol} / \mathrm{L}$ among about 9,000 patients with CKD (about 3,000 of whom were to be on dialysis at randomization). The first United Kingdom-Heart and Renal Protection (UK-HARP-1) pilot study ${ }^{8}$ indicated that, to obtain an average absolute reduction in LDL cholesterol of $1 \mathrm{mmol} / \mathrm{L}$ in a large-scale trial lasting 4 to 5 years, it was likely to be necessary to use a regimen that could reduce LDL cholesterol by about $45 \%$ to $50 \%$. To achieve such a reduction without the use of high statin doses (which are associated with an increased risk of myopathy, ${ }^{9}$ especially in patients with impaired renal function ${ }^{10}$ ), a low dose of a statin (simvastatin $20 \mathrm{mg}$ daily) was combined with the cholesterol-absorption inhibitor ezetimibe, and the biochemical efficacy and tolerability of this regimen were confirmed in the UK-HARP-II pilot study. ${ }^{11}$
Inclusion and exclusion criteria

Inclusion criteria

- History of CKD

○ Predialysis (blood creatinine $\geq 1.7 \mathrm{mg} / \mathrm{dL}[\geq 150$ $\mu \mathrm{mol} / \mathrm{L}]$ in men or $\geq 1.5 \mathrm{mg} / \mathrm{dL}[\geq 130 \mu \mathrm{mol} / \mathrm{L}]$ in women at both the most recent routine clinic visit and the study screening visit) or

$\circ$ Dialysis (hemodialysis or peritoneal dialysis)

- Men or women aged $\geq 40$ years

Exclusion criteria

- Definite history of MI or coronary revascularization procedure

- Functioning renal transplant or living donor renal transplant planned

- Less than 2 months since presentation as an acute uremic emergency

- Definite history of chronic liver disease or abnormal liver function (ie, ALT $>1.5 \times$ ULN or, if ALT not available, AST $>1.5 \times$ ULN) (patients with a history of hepatitis are eligible if these limits are not exceeded)

- Evidence of active inflammatory muscle disease (eg, dermatomyositis, polymyositis) or CK $>3 \times$ ULN

- Definite previous adverse reaction to a statin or to ezetimibe

- Concurrent treatment with a contraindicated drug:

○ Hydroxymethylglutaryl-coenzyme A reductase inhibitor ("statin")

$\circ$ Ezetimibe

Fibric acid derivative ("fibrate")

$\circ$ Nicotinic acid

$\circ$ Ciclosporin

$\circ$ Macrolide antibiotic (erythromycin, clarithromycin)

$\circ$ Systemic use of imidazole or triazole antifungals (eg, itraconazole, ketoconazole)

$\circ$ Protease-inhibitors (eg, antiretroviral drugs for HIV infection)

- Nefazodone

- Child-bearing potential (ie, premenopausal woman who is not using a reliable method of contraception)

- Known to be poorly compliant with clinic visits or prescribed medication

- Medical history that might limit the individual's ability to take the trial treatments for the duration of the study (eg, severe respiratory disease, history of cancer other than nonmelanoma skin cancer, or recent history of alcohol or substance misuse) 


\section{Figure 1}

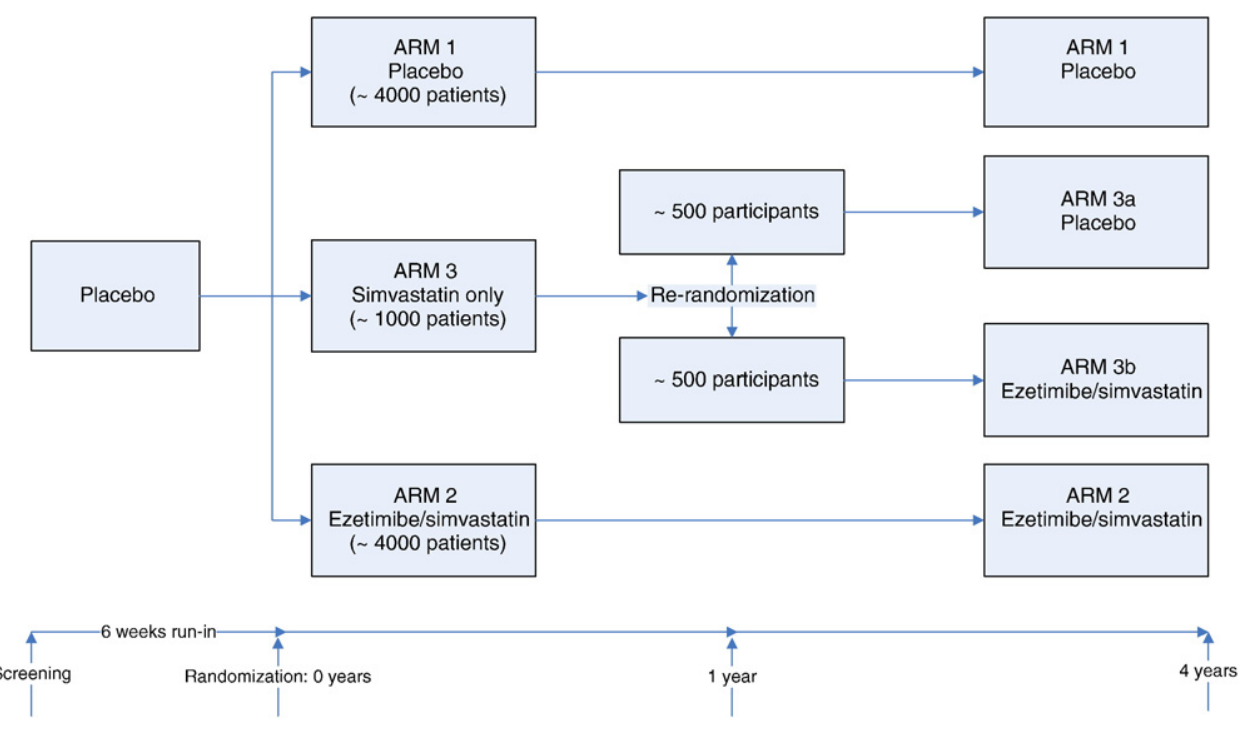

SHARP randomization structure.

Although the chief aim of SHARP is to determine any vascular benefits of LDL lowering among patients with advanced $\mathrm{CKD}$, the trial also provides an opportunity to test the hypothesis that lowering LDL cholesterol might reduce the rate of loss of renal function. ${ }^{12}$ Among people without known CKD, meta-analyses of randomized trials have suggested that statin therapy might reduce the rate of loss of eGFR by about one third ${ }^{13,14}$; so a similar proportional effect among patients with advanced CKD, in whom there is rapid loss of renal function, would yield a worthwhile delay in the need for renal replacement therapy (ie, dialysis or transplantation).

In this article, we describe the SHARP trial design, patient characteristics, early safety data, lipid effects, and statistical analysis plan.

\section{Methods}

\section{Aims}

SHARP aims to assess the efficacy and safety of lowering LDL cholesterol with the combination of ezetimibe $10 \mathrm{mg}$ plus simvastatin $20 \mathrm{mg}$ (ezetimibe/simvastatin $10 / 20 \mathrm{mg}$ ) daily among men or women aged at least 40 years without known CHD (prior MI or coronary revascularization) who had evidence of CKD (determined by screening creatinine $\geq 1.7 \mu \mathrm{mg} / \mathrm{dL} \quad[\geq 150 \mu \mathrm{mol} / \mathrm{L}]$ in $\mathrm{men}$ or $\geq 1.5 \mathrm{mg} / \mathrm{dL}$ $[\geq 130 \mu \mathrm{mol} / \mathrm{L}]$ in women; Box). It was intended to recruit about 3,000 CKD patients requiring dialysis and 6,000 not on dialysis. Using a "double-dummy" method to maintain blinding for both patients and physicians, patients were randomized in a ratio of $4: 4: 1$ to ezetimibe/simvastatin 10/ $20 \mathrm{mg}$ daily versus matching placebo versus simvastatin 20 mg daily (Figure 1). After 1 year, patients initially allocated simvastatin $20 \mathrm{mg}$ daily alone (who formed a comparison group for the assessment of any early adverse effects of ezetimibe) were rerandomized to ezetimibe/simvastatin 10/20 mg daily versus placebo for the remainder of the scheduled study treatment period.

\section{Sample size and predicted number of events}

A meta-analysis of statin trials available in 2000 (which was subsequently published ${ }^{3}$ ) indicated that statin therapy produced a reduction of about one quarter in major vascular events (defined as cardiac death, nonfatal MI, coronary revascularization, or stroke) per 1-mmol/L LDL cholesterol reduction. Based on the expectation that ezetimibe/simvastatin $10 / 20 \mathrm{mg}$ would reduce LDL cholesterol by an average of $39 \mathrm{mg} / \mathrm{dL}(1 \mathrm{mmol} / \mathrm{L})$ in the SHARP trial, together with the assumption that about one fifth of cardiac deaths might be nonatherosclerotic (and, hence, potentially not susceptible to prevention by lowering LDL cholesterol), it was hypothesized that the risk of major vascular events might be reduced by $20 \%$. The annual incidence of major vascular events was projected to be about 5\% among CKD patients on dialysis at baseline and about $3 \%$ among those who were not, so the average event rate during follow-up was estimated to be $3.7 \%$ per annum (based on $1: 2$ ratio of these groups). Under these assumptions, a study in which all patients were followed for at least 4 years from trial entry, yielding at least 1,100 major vascular events, would have $90 \%$ power at $P<$ .01 (2-sided).

Based on the UK-HARP-I pilot study ${ }^{8}$ and the RENAAL study, ${ }^{15}$ the cumulative incidence of end-stage renal disease (defined as starting long-term dialysis or transplantation) among patients not on dialysis at baseline was expected to be about $20 \%$ after 4 years. Consequently, the inclusion of 6,000 such patients in SHARP provides $>95 \%$ power at $P<.01$ (2-sided) to detect a $20 \%$ relative reduction in the risk of endstage renal disease. 
Table I. Baseline demographic characteristics, overall and by renal status at randomization

\begin{tabular}{|c|c|c|c|}
\hline & Not on dialysis & On dialysis & All patients \\
\hline Number randomized & 6382 & 3056 & 9438 \\
\hline \multicolumn{4}{|l|}{ Renal diagnosis } \\
\hline Glomerulonephritis & $1063(17 \%)$ & $689(23 \%)$ & $1752(19 \%)$ \\
\hline Diabetic nephropathy & $916(15 \%)$ & $477(16 \%)$ & $1393(15 \%)$ \\
\hline Hypertensive or renovascular disease & $1334(22 \%)$ & $482(16 \%)$ & $1816(20 \%)$ \\
\hline Cystic kidney disease & $690(11 \%)$ & $374(12 \%)$ & $1064(12 \%)$ \\
\hline Pyelonephritis/obstructive nephropathy & $413(7 \%)$ & $202(7 \%)$ & $615(7 \%)$ \\
\hline Other known cause & $911(15 \%)$ & $373(12 \%)$ & $1284(14 \%)$ \\
\hline Unknown cause & $796(13 \%)$ & $403(13 \%)$ & $1199(13 \%)$ \\
\hline Unavailable & 259 & 56 & 315 \\
\hline \multicolumn{4}{|l|}{ Age, y } \\
\hline Mean (SD) & $62.3(11.7)$ & $58.9(11.8)$ & $61.2(11.9)$ \\
\hline $40-49$ & $1099(17 \%)$ & $825(27 \%)$ & $1924(20 \%)$ \\
\hline $50-59$ & $1516(24 \%)$ & $826(27 \%)$ & $2342(25 \%)$ \\
\hline $60-69$ & $1794(28 \%)$ & $740(24 \%)$ & $2534(27 \%)$ \\
\hline $70+$ & $1973(31 \%)$ & $665(22 \%)$ & $2638(28 \%)$ \\
\hline \multicolumn{4}{|l|}{ Sex } \\
\hline Men & $3954(62 \%)$ & $1946(64 \%)$ & $5900(63 \%)$ \\
\hline Women & $2428(38 \%)$ & $1110(36 \%)$ & $3538(37 \%)$ \\
\hline \multicolumn{4}{|l|}{ Physical measurements } \\
\hline Systolic blood pressure, $\mathrm{mm} \mathrm{Hg}$ & $139(21)$ & $139(24)$ & $139(22)$ \\
\hline Diastolic blood pressure, $\mathrm{mm} \mathrm{Hg}$ & $80(13)$ & $78(13)$ & 79 (13) \\
\hline Body mass index, $\mathrm{kg} / \mathrm{m}^{2}$ & $27.4(5.5)$ & $26.4(5.8)$ & $27.1(5.6)$ \\
\hline Waist circumference, $\mathrm{cm}$ & $96.7(14.8)$ & $97.0(15.7)$ & $96.8(15.1)$ \\
\hline \multicolumn{4}{|l|}{ Smoking } \\
\hline Current smoker & $791(12 \%)$ & $475(16 \%)$ & $1266(13 \%)$ \\
\hline \multicolumn{4}{|l|}{ Prior diseases ${ }^{\star}$} \\
\hline Angina & $212(3 \%)$ & $77(3 \%)$ & $289(3 \%)$ \\
\hline Peripheral arterial disease & $371(6 \%)$ & $229(7 \%)$ & $600(6 \%)$ \\
\hline Cerebrovascular disease & $464(7 \%)$ & $187(6 \%)$ & $651(7 \%)$ \\
\hline Any vascular disease & $933(15 \%)$ & $437(14 \%)$ & $1370(15 \%)$ \\
\hline Diabetes & $1429(22 \%)$ & $650(21 \%)$ & $2079(22 \%)$ \\
\hline \multicolumn{4}{|l|}{ Ethnic group } \\
\hline White & 4567 (72\%) & 2206 (72\%) & $6773(72 \%)$ \\
\hline Black & $130(2 \%)$ & $146(5 \%)$ & $276(3 \%)$ \\
\hline Chinese & $1031(16 \%)$ & $109(4 \%)$ & 1140 (12\%) \\
\hline Other Asian & $528(8 \%)$ & 442 (14\%) & $970(10 \%)$ \\
\hline Other/not specified & $126(2 \%)$ & $153(5 \%)$ & $279(3 \%)$ \\
\hline
\end{tabular}

Mean (SD) or number (percentage) shown.

* Cerebrovascular disease includes stroke and transient ischemic attack. Any vascular disease is defined as a history of angina, peripheral arterial disease, or cerebrovascular disease at the screening visit.

\section{Results}

\section{Screening clinic visit}

SHARP has been conducted in 380 hospitals in 18 countries. Between June 2003 and June 2006, 11,792 potentially eligible CKD patients attended the study screening visits. Medical history and other eligibility criteria were checked (Box), and 11,364 (96\%) eligible patients agreed to participate. Among these patients, written informed consent was obtained; blood pressure, height, weight, and waist circumference were measured; nonfasting blood was taken for local laboratory assays (lipid profile, creatine kinase $[\mathrm{CK}]$, alanine aminotransferase [ALT] or aspartate aminotransferase [AST], creatinine); and single-blind study placebo tablets were provided. Study data were entered directly into electronic case-report forms on dedicated laptop computers.

\section{Run-in period before randomization}

During run-in, the patient's physicians were provided with a summary of the screening data for each of their patients, including the results of local laboratory blood assays on screening blood samples. Randomization could be considered at the end of the run-in period only if the responsible physician (typically the nephrologist) confirmed that this was appropriate and no objection had been raised by any other physician caring for the patient. Patients who were noncompliant (ie, took $<90 \%$ of run-in treatment) or who were thought likely to have difficulties in attending clinics for any reason were not to be randomized. Hence, in addition to allowing a review by the patient's physicians, the run-in period allowed many potential dropouts to be excluded before being randomized, with a consequent improvement in statistical sensitivity. ${ }^{16}$ 


\section{Randomization clinic visit}

Participating patients returned for a randomization appointment approximately 6 weeks after the screening visit. Those who had not had a serious adverse event rendering them ineligible during the run-in period (eg, MI) and who had not commenced a contraindicated drug (eg, statin) were asked if they were still willing to take study treatment for at least 4 years. A total of 1,926 patients entered run-in but were not randomized. Of these, 1,678 dropped out before the randomization visit, with the reasons given including $(>1$ reason was possible) the following: patient's request (23\%), physician's request (44\%), ineligible screening blood result (32\%), or some other reason (11\%). A further 248 patients attended the randomization visit but were not randomized, generally because of poor compliance during run-in or their reluctance to continue. Patients who agreed to be randomized provided nonfasting blood samples and, if not on dialysis, a urine sample, and were asked for their consent for long-term storage of plasma, DNA, and urine for unspecified future analyses. Samples were cooled, spun, and separated locally, whereupon plasma and whole blood aliquots were stored locally at $-40^{\circ} \mathrm{C}$ before shipment on dry ice to the central laboratory (Wolfson Laboratories, CTSU, University of Oxford, United Kingdom). Patients were allocated their study treatment using a minimized randomization algorithm on the laptop computer (which was synchronized regularly with the central database) to help ensure balance with respect to important prognostic characteristics. ${ }^{17}$

A total of 9,438 CKD patients were randomized, of whom 3,056 were receiving maintenance dialysis $(2,556$ hemodialysis and 500 peritoneal dialysis) and 6,382 were not (Table I). The most common recorded causes of renal disease were glomerulonephritis (19\%), diabetic nephropathy (15\%), and hypertensive or renovascular disease (20\%). Mean age was 61 years (SD 12), 63\% were male, mean blood pressure was $139 / 79 \mathrm{~mm} \mathrm{Hg}$, mean body mass index was 27.1 (SD 5.6$) \mathrm{kg} / \mathrm{m}^{2}$, and $22 \%$ had diabetes. Patients who had a prior history of MI or coronary revascularization were not eligible, but $15 \%$ had some other vascular disease (eg, angina pectoris, stroke, or peripheral vascular disease). About three quarters of the study population were white, whereas $3 \%$ were black, $12 \%$ were Chinese, and 10\% were other Asian.

Among the 6,382 patients not on dialysis at randomization, the average eGFR, calculated with the Modified Diet and Renal Disease equation ${ }^{18}$, was 26.5 (SD 13.0) $\mathrm{mL} / \mathrm{min} / 1.73 \mathrm{~m}^{2}$ (Table II). About two fifths of the patients not on dialysis had Kidney Disease Outcomes Quality Initiative ${ }^{19}$ stage 3 disease (eGFR of $30-59 \mathrm{~mL} /$ $\min / 1.73 \mathrm{~m}^{2}$ ), two fifths had stage 4 disease (eGFR of $15-29 \mathrm{~mL} / \mathrm{min} / 1.73 \mathrm{~m}^{2}$ ), and one fifth had stage 5 disease (eGFR $<15 \mathrm{~mL} / \mathrm{min} / 1.73 \mathrm{~m}^{2}$ ). Among the 5,681 (89\%) nondialysis patients who had a measurement of urinary albumin to creatinine ratio (ACR), about one fifth had
Table II. Laboratory values at randomization, overall and by renal status at randomization

\begin{tabular}{|c|c|c|c|}
\hline & $\begin{array}{l}\text { Not on } \\
\text { dialysis }\end{array}$ & $\begin{array}{l}\text { On } \\
\text { dialysis }\end{array}$ & $\begin{array}{c}\text { All } \\
\text { patients }\end{array}$ \\
\hline $\begin{array}{l}\text { Number randomized } \\
\text { eGFR, } \mathrm{mL} / \mathrm{min} / 1.73 \mathrm{~m}^{2}\end{array}$ & 6382 & 3056 & 9438 \\
\hline Mean (SD) & $26.5(13.0)$ & - & - \\
\hline$<15$ & $1237(20 \%)$ & - & - \\
\hline $15-29$ & $2628(43 \%)$ & - & - \\
\hline $30-59$ & $2197(36 \%)$ & - & - \\
\hline $60-89$ & $67(1 \%)$ & - & - \\
\hline$\geq 90$ & $21(0 \%)$ & - & - \\
\hline Missing & 232 & & \\
\hline \multicolumn{4}{|l|}{ Urinary ACR } \\
\hline Normal & $1124(20 \%)$ & - & - \\
\hline Microalbuminuria & $2125(37 \%)$ & - & - \\
\hline Macroalbuminuria & $2432(43 \%)$ & - & - \\
\hline Missing & 701 & & \\
\hline \multicolumn{4}{|l|}{ Lipids } \\
\hline $\begin{array}{l}\text { Number with baseline } \\
\text { LDL cholesterol analyzed }\end{array}$ & $6149(96 \%)$ & $2895(95 \%)$ & $9044(96 \%)$ \\
\hline Total cholesterol, mg/dL & $194(45)$ & $179(45)$ & $189(45)$ \\
\hline LDL cholesterol, mg/dL & $111(33)$ & $100(33)$ & $108(34)$ \\
\hline HDL cholesterol, mg/dL & $44(13)$ & $42(13)$ & $43(13)$ \\
\hline Triglycerides, mg/dL & $206(146)$ & 206 (164) & 206 (152) \\
\hline Apolipoprotein B, mg/dL & $99(25)$ & $92(26)$ & $96(26)$ \\
\hline Apolipoprotein $\mathrm{A}_{1}, \mathrm{mg} / \mathrm{dL}$ & $136(29)$ & $129(27)$ & $134(29)$ \\
\hline $\begin{array}{l}\text { Apolipoprotein B: } \\
\text { apolipoprotein } A_{1}\end{array}$ & $0.75(0.23)$ & $0.74(0.24)$ & $0.75(0.24)$ \\
\hline
\end{tabular}

Mean (SD) or number (percentage) shown. Microalbuminuria is defined as an ACR $\geq 30$ and $\leq 300 \mathrm{mg} / \mathrm{g}$. Macroalbuminuria is defined as ACR $>300 \mathrm{mg} / \mathrm{g}$. To convert milligrams per deciliter to millimoles per liter, multiply by 0.02586 for cholesterol and by 0.01129 for triglycerides; to convert apolipoprotein $A_{1}$ and $B$ from milligrams per deciliter to grams per liter, divide by 100 .

values in the reference range (ACR $<30 \mathrm{mg} / \mathrm{g}$ ), two fifths had microalbuminuria (ACR $\geq 30$ and $\leq 300 \mathrm{mg} / \mathrm{g}$ ), and two fifths had macroalbuminuria (ACR $>300 \mathrm{mg} / \mathrm{g}$ ). Overall, among the 9,044 patients for whom a blood sample was available at randomization, mean plasma concentrations were 189 (SD 45) $\mathrm{mg} / \mathrm{dL}$ for total cholesterol, 108 (SD 34) $\mathrm{mg} / \mathrm{dL}$ for LDL cholesterol, 43 (SD 13) $\mathrm{mg} / \mathrm{dL}$ for high-density lipoprotein (HDL) cholesterol, and 206 (SD 152, interquartile range 119-249) $\mathrm{mg} / \mathrm{dL}$ for triglycerides. Mean LDL cholesterol concentration was lower among patients on dialysis than those who were not (100 vs $111 \mathrm{mg} / \mathrm{dL}, P<.0001$ ).

Aspirin or other antiplatelet therapy was being prescribed at baseline to $22 \%$ of randomized patients and an oral anticoagulant to $4 \%$ (Table III). As expected in this high-risk CKD population, a high proportion were receiving angiotensin-converting-enzyme (ACE) inhibitors (35\% of all patients), angiotensin-receptor blockers (23\%), calcium-channel blockers (41\%), $\beta$-blockers (37\%), and diuretics $(42 \%)$, with many $(60 \%)$ receiving $>1$ of these agents.

\section{Postrandomization follow-up visits}

Participants were to be seen in the study clinics for routine follow-up at 2 months, at 6 months, and then 
Table III. Medication use at randomization, overall and by renal status at randomization

\begin{tabular}{|c|c|c|c|}
\hline & $\begin{array}{l}\text { Not on } \\
\text { dialysis }\end{array}$ & $\begin{array}{l}\text { On } \\
\text { dialysis }\end{array}$ & $\begin{array}{c}\text { All } \\
\text { patients }\end{array}$ \\
\hline Number randomized & 6382 & 3056 & 9438 \\
\hline Antiplatelet therapy & $1207(19 \%)$ & $871(29 \%)$ & $2078(22 \%)$ \\
\hline Oral anticoagulant & $211(3 \%)$ & $167(5 \%)$ & $378(4 \%)$ \\
\hline ACE inhibitor & $2537(40 \%)$ & $813(27 \%)$ & $3350(35 \%)$ \\
\hline $\begin{array}{l}\text { Angiotensin II receptor } \\
\text { blocker }\end{array}$ & $1657(26 \%)$ & 488 (16\%) & $2145(23 \%)$ \\
\hline Calcium-channel blocker & $2819(44 \%)$ & $1087(36 \%)$ & $3906(41 \%)$ \\
\hline$\beta$-Blocker & $2349(37 \%)$ & 1181 (39\%) & $3530(37 \%)$ \\
\hline Diuretic & $2869(45 \%)$ & $1062(35 \%)$ & $3931(42 \%)$ \\
\hline $\begin{array}{l}\text { Miscellaneous blood } \\
\text { pressure-lowering } \\
\text { drug }\end{array}$ & $1201(19 \%)$ & $563(18 \%)$ & 1764 (19\%) \\
\hline Phosphate binder & $1021(16 \%)$ & $2479(81 \%)$ & $3500(37 \%)$ \\
\hline $\begin{array}{l}\text { Erythropoietin-stimulating } \\
\text { agent }\end{array}$ & 779 (12\%) & $1724(56 \%)$ & $2503(27 \%)$ \\
\hline $\begin{array}{l}\text { Iron-containing } \\
\text { preparation }\end{array}$ & $845(13 \%)$ & $1319(43 \%)$ & $2164(23 \%)$ \\
\hline Vitamin D supplement & $1313(21 \%)$ & 1539 (50\%) & $2852(30 \%)$ \\
\hline
\end{tabular}

every 6 months until the final follow-up visits between March and August 2010 (minimum of 4 years for all patients). It was also possible to arrange an "early recall" visit for any participant who required review outside of his or her planned visit schedule. At each follow-up, compliance with study treatment was reviewed, any unexplained muscle pain and nonstudy treatment recorded, and blood pressure measured. Samples of nonfasting blood were taken for local laboratory assay of CK, liver transaminases (ALT or AST), and creatinine. Information was to be recorded about any suspected MI, stroke, vascular procedure, cancer, or other serious adverse event (together with the reasons for all hospital admissions, including day cases), irrespective of compliance with study treatment. If a participant became unwilling or unable to attend his or her scheduled follow-up visits, information about any serious adverse events was to be obtained from them by telephone or by direct correspondence with their own physicians until the scheduled end of the study. Local study staff aimed to obtain extra information from hospital records and other appropriate sources about all reports of serious adverse events that are of particular interest for the study aims (ie, death, MI, angina, heart failure, stroke, transient ischemic attack, revascularization procedure, angiography, amputation, initiation of dialysis, kidney transplant, cancer, myopathy, rhabdomyolysis, hepatitis, or gallbladder disease). This information has been sent to the International Coordinating Centre for further review and central adjudication in accordance with prespecified definitions by trained clinicians who are blind to treatment allocation.

\section{Effects of study treatment on blood lipids}

The protocol specified that central analysis of blood lipid concentrations was to be conducted on blood samples collected from about $10 \%$ of participants at their 1- and 4-year follow-up visits and from all participants at their 2.5-year visits, and that unblinded lipid differences were to be periodically reviewed by the Steering Committee to monitor study power. The sampling procedure at 1 and 4 years was designed to ensure that the sample was representative of the whole study population, particularly in regard to the proportions recruited in each country and in the proportions of nondialysis and dialysis patients. The 1- and 4-year samples were each collected during separate calendar periods of approximately 6 months during the trial, with the aim of sampling about $10 \%$ of patients from around one third of each country's sites during those periods. Blood samples at randomization and 1 year were available for 787 participants (91\% of those alive and selected for sampling) and at randomization and 2.5 years from 6,632 participants (86\%), with collection of 4-year samples still in progress at the time of this report. In the case of nonattendance when scheduled to provide a blood sample, a patient's randomization lipid parameters were imputed based on the assumption that the patient was not taking study treatment at that time. Compared with placebo, allocation to ezetimibe/simvastatin yielded mean reductions in LDL cholesterol concentrations of 43 (SE 2.2) $\mathrm{mg} / \mathrm{dL}$ at 1 year and of 33 (SE 0.8) $\mathrm{mg} / \mathrm{dL}$ at 2.5 years (Table IV).

\section{Safety of study treatment at 1 year}

Because relatively little information was available about the safety of ezetimibe at the time that SHARP was initiated, the protocol included a simvastatin-alone arm and prespecified that unblinded information on a limited number of safety outcomes (but not on study outcomes) was to be reviewed by the Steering Committee after each patient had completed 1 year of follow-up. Compared with the 1,054 patients who were allocated simvastatin alone (as well as with the 4,191 patients allocated placebo), no significant excesses were observed among the 4,193 allocated ezetimibe/simvastatin in any of these safety outcomes (Table V). About 10\% of patients reported muscle pain during the first year, but there was no significant excess among the patients allocated ezetimibe/simvastatin. Few elevations in CK to between $5 \times$ and $10 \times$ the upper limit of normal (ULN) or above $10 \times$ ULN were observed and, again, the rates were similar in each randomized group. There were only 7 confirmed cases of myopatby (defined as CK $>10 \times$ ULN plus muscle symptoms or evidence of organ damage), 5 of which were in patients allocated placebo, including 1 case of rhabdomyolysis (defined as myopathy with CK $>40 \times$ ULN plus evidence of end-organ damage) in a patient 
Table IV. Biochemical efficacy at 1 and 2.5 years, by initial randomized treatment allocation

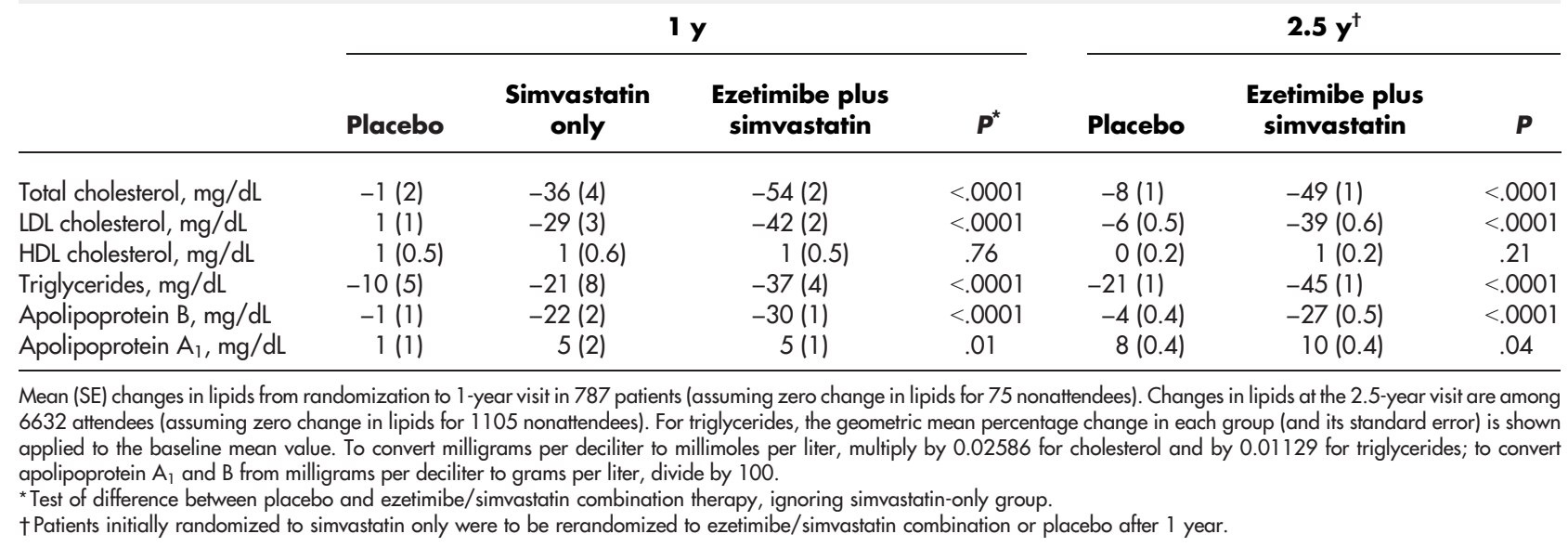

Table V. Safety at 1 year by initial randomized treatment allocation

\begin{tabular}{|c|c|c|c|c|c|}
\hline & Placebo & Simvastatin only & Ezetimibe plus simvastatin & $\boldsymbol{P}^{*}$ & $\mathbf{P}^{\dagger}$ \\
\hline Number randomized & 4191 & 1054 & 4193 & & \\
\hline Muscle pain & $393(9.4 \%)$ & $103(9.8 \%)$ & $430(10.3 \%)$ & .19 & .68 \\
\hline \multicolumn{6}{|l|}{ CK } \\
\hline \multicolumn{6}{|l|}{$>5 \times$ but $\leq 10 \times$ ULN } \\
\hline Asymptomatic & $11(0.3 \%)$ & $5(0.5 \%)$ & $16(0.4 \%)$ & .44 & .88 \\
\hline Muscle symptoms present & $3(0.1 \%)$ & $1(0.1 \%)$ & $1(0.0 \%)$ & .62 & .86 \\
\hline \multicolumn{6}{|l|}{$>10 \times$ but $\leq 40 \times$ ULN } \\
\hline \multirow{2}{*}{\multicolumn{6}{|c|}{$\begin{array}{l}\text { Not on dialysis }{ }^{\ddagger} \\
\text { No end-organ damage } \S\end{array}$}} \\
\hline & & & & & \\
\hline Asymptomatic & $0(0.0 \%)$ & $1(0.1 \%)$ & $0(0.0 \%)$ & - & .46 \\
\hline Muscle symptoms present & $0(0.0 \%)$ & $0(0.0 \%)$ & $0(0.0 \%)$ & - & - \\
\hline With end-organ damage ${ }^{\S}$ & $4(0.1 \%)$ & $0(0.0 \%)$ & $1(0.0 \%)$ & .37 & 1.0 \\
\hline \multicolumn{6}{|l|}{ On dialysis ${ }^{\ddagger}$} \\
\hline Asymptomatic & $1(0.0 \%)$ & $0(0.0 \%)$ & $2(0.0 \%)$ & 1.0 & 1.0 \\
\hline Muscle symptoms present & $0(0.0 \%)$ & $0(0.0 \%)$ & $1(0.0 \%)$ & 1.0 & 1.0 \\
\hline \multicolumn{6}{|l|}{$>40 \times$ ULN } \\
\hline \multicolumn{6}{|l|}{ Not on dialysis ${ }^{\ddagger}$} \\
\hline With end-organ damage ${ }^{\S}$ & $1(0.0 \%)$ & $0(0.0 \%)$ & $0(0.0 \%)$ & 1.0 & - \\
\hline Persistently elevated liver transaminases" & $5(0.1 \%)$ & $0(0.0 \%)$ & $7(0.2 \%)$ & .77 & .39 \\
\hline \multicolumn{6}{|l|}{ Hepatitis" } \\
\hline Infective & $6(0.1 \%)$ & $1(0.1 \%)$ & $6(0.1 \%)$ & 1.0 & 1.0 \\
\hline Noninfective & $1(0.0 \%)$ & $0(0.0 \%)$ & $2(0.0 \%)$ & 1.0 & 1.0 \\
\hline No cause identified & $1(0.0 \%)$ & $1(0.1 \%)$ & $2(0.0 \%)$ & 1.0 & 1.0 \\
\hline \multicolumn{6}{|l|}{ Complications of gallstones } \\
\hline Acute pancreatitis & $5(0.1 \%)$ & $0(0.0 \%)$ & $4(0.1 \%)$ & 1.0 & .70 \\
\hline Other complications & $19(0.5 \%)$ & $3(0.3 \%)$ & $17(0.4 \%)$ & .87 & .77 \\
\hline Hospitalization with gallstones ${ }^{\#}$ & $4(0.1 \%)$ & $4(0.4 \%)$ & $2(0.0 \%)$ & .68 & .02 \\
\hline \multicolumn{6}{|l|}{ Pancreatitis } \\
\hline Acute (excluding gallstones) & $7(0.2 \%)$ & $1(0.1 \%)$ & $2(0.0 \%)$ & .18 & 1.0 \\
\hline Chronic & $1(0.0 \%)$ & $0(0.0 \%)$ & 0 (0.0\%) & 1.0 & - \\
\hline
\end{tabular}

*Test of difference between ezetimibe/simvastatin combination therapy and placebo.

$\dagger$ Test of difference between ezetimibe/simvastatin combination therapy and simvastatin only.

$\ddagger$ At the time of presentation with raised CK.

$\S$ End-organ damage is defined as acute initiation of dialysis or a $>20 \%$ rise in serum creatinine. Among patients already on dialysis, it is not possible to determine if end-organ damage has occurred.

$\|$ At least 2 consecutive ALT or AST $>3 \times$ ULN without other indication of hepatitis.

IInfective hepatitis—definite evidence of an infective cause; noninfective hepatitis-definite evidence of a noninfective cause; no cause identified-includes cases with negative viral serology result and those with no viral serology result available.

\#With no reported complications. 
allocated placebo (who was not taking a nonstudy statin). No excesses were observed of persistent liver transaminase elevations, hepatitis, gallstone complications, or pancreatitis.

\section{Discussion}

Statin therapy is now widely recommended for the primary and secondary prevention of vascular disease in a wide range of people, ${ }^{20-22}$ but 2 previous trials have failed to show a clear benefit among patients with end-stage renal failure who were undergoing dialysis. $^{6,7}$ Consequently, there remains considerable uncertainty as to whether lowering LDL cholesterol is of value among dialysis patients, as well as among those with less severe renal impairment who have not yet commenced dialysis. The SHARP trial, which has recruited $>9,000$ patients with advanced $\mathrm{CKD}, 3,000$ on dialysis and 6,000 not, can help to address this clinical uncertainty.

In the International Conference on HarmonisationGood Clinical Practice Statistical Principles for Clinical Trials, it is recommended that checks are made during a trial that its actual performance has not affected statistical power, that assumptions underlying the original design remain plausible, and that the statistical analysis plan remains appropriate in the light of emerging results from other relevant trials. ${ }^{23}$ The guidelines indicate that, until the study treatment has been unblinded, it is appropriate to make any changes that might help the trial to provide more reliable information about the effects of treatment. In particular, it is stated that "The primary variable ... should be the variable capable of providing the most clinically relevant and convincing evidence directly related to the primary objective of the trial." ${ }^{23}$ The overall incidence rate for major vascular events (4.3\% per annum) in SHARP was slightly higher than had been anticipated; but blinded central adjudication showed that about one third of these events were noncoronary cardiac deaths or hemorrhagic strokes, which an updated meta-analysis of statin trials has indicated are not prevented by LDL-lowering therapy. ${ }^{4}$ In addition, unblinded review of the lipid assays in SHARP showed that the mean LDL cholesterol reduction at 2.5 years (ie, at about the midpoint of the trial) was $33 \mathrm{mg} / \mathrm{dL}$, rather than the anticipated difference of $39 \mathrm{mg} / \mathrm{dL}$. Based on the larger-than-expected proportion of major vascular events that were nonatherosclerotic (and so not likely to be reduced by LDL-lowering therapy) and the smaller-thanexpected reduction in LDL cholesterol, a relative risk reduction of $13 \%$ in the original primary outcome of major vascular events may be all that can realistically be expected. Table VI indicates that SHARP would have only $66 \%$ power at $P=.01$ (2-sided) to detect such a difference among the $\sim 8400$ patients initially randomized to ezetimibe/simvastatin versus placebo (Arm 2 versus
Table VI. Improvement in study power by changing to new primary outcome comparison

\begin{tabular}{ccccc} 
Outcome & $\begin{array}{c}\text { Anticipated } \\
\text { proportional } \\
\text { reduction* }^{\star}\end{array}$ & $\mathbf{n}^{\dagger}$ & $\begin{array}{c}\text { Expected } \\
\text { result (active } \\
\text { vs placebo) }\end{array}$ & $\begin{array}{c}\text { Power at } \\
\mathbf{2 P}=.01\end{array}$ \\
\hline $\begin{array}{c}\text { Original } \\
\text { primary }\end{array}$ & $13 \%$ & $\sim 8400$ & 737 versus 845 & $66 \%$ \\
New & $13 \%$ & $\sim 9400$ & 807 versus 927 & $72 \%$ \\
primary & $18 \%$ & $\sim 8400$ & 525 versus 639 & $84 \%$ \\
& $18 \%$ & $\sim 9400$ & 576 versus 701 & $88 \%$ \\
\hline
\end{tabular}

*Treatment effects estimated using data from the Cholesterol Treatment Trialists Collaboration. ${ }^{4}$

† Sample size is increased from 8400 to $~ 9400$ by the inclusion of participants randomized to simvastatin only for the first year and subsequently randomized to ezetimibe/simvastatin versus placebo. For these participants, events are only counted in the primary outcome if they occur after the second randomization.

$\ddagger$ Based on blinded outcome event rates in November 2009.

Arm 1 in Figure), which is the population specified in the protocol for the primary comparison.

SHARP is overseen by an independent Steering Committee that includes nephrologists, cardiologists, clinical trialists, and statisticians, with 2 nonvoting observers from the funder. The independent sponsor is the University of Oxford, and the trial is funded by the supplier of the study drugs (Merck \& Co). Changes to the study plans in response to a revision of the underlying sample size assumptions are entirely appropriate provided that care is taken to avoid bias by, as in the case of SHARP, remaining blind to the effects of study treatment on the efficacy outcomes. ${ }^{23,24}$ Consequently, in October 2009, the Steering Committee decided to change the primary outcome to major atherosclerotic events, defined as the combination of MI, coronary death, ischemic stroke, or any revascularization procedure (ie, exclusion of noncoronary cardiac deaths and strokes confirmed to be hemorrhagic from the original major vascular event outcome). A relative risk reduction of $18 \%$ in this revised outcome seems realistic, and Table VI shows that SHARP has good statistical power to detect such an effect among the 8,400 patients initially randomized to ezetimibe/ simvastatin versus placebo. Moreover, because even better power can be achieved by including those patients who were randomly allocated between ezetimibe/simvastatin versus placebo following allocation to simvastatin for 1 year (ie, arm 3b vs $3 \mathrm{a}$ in Figure 1), the Steering Committee decided that the main comparisons should include them. These and other changes are described in the revised statistical analysis plan for SHARP (online Appendix A).

The independent sponsor is required by its contract with the funder to seek its formal agreement to any protocol change, but the funder declined to approve the changes agreed by the Steering Committee. Although it is not possible to revise the protocol accordingly, the Steering Committee is free to change the statistical analysis plan as it considers appropriate while it remains blind to the effects of treatment on efficacy end points. 
The present report and related appendices are, therefore, intended to record that the chief emphasis for evaluating the efficacy of study treatment in SHARP will now not be on the primary outcome in the protocol of major vascular events, but will instead be on the new key outcome of major atherosclerotic events. This change of emphasis should help to reduce the risk of a false-negative result (in which a potential beneficial effect on atherosclerotic outcomes is diluted by a lack of benefit on nonatherosclerotic components), a scenario that would have adverse consequences for patients.

During the conduct of SHARP, an unexpected concern was raised by the SEAS placebo-controlled trial of ezetimibe $10 \mathrm{mg}$ plus simvastatin $20 \mathrm{mg}$ daily among 1,873 people with moderate aortic stenosis about an apparent excess risk of cancer (105 on ezetimibe plus simvastatin vs 70 on placebo, $P=.01) .^{25}$ The SHARP investigators received agreement from its Data Monitoring Committee to access unblinded data on incident cancers (but no other clinical events), as did the investigators for IMPROVE-IT, which is comparing simvastatin plus ezetimibe versus simvastatin among 18,000 patients with acute coronary syndrome. ${ }^{26}$ When these interim data on cancer were examined together in a meta-analysis, ${ }^{27}$ they did not provide support for the hypothesis that ezetimibe might cause cancer; and their Data Monitoring Committees recommended that each trial continue. Completion of SHARP in 2010 (and, subsequently, of IMPROVE-IT in 2013) will provide additional evidence about the effects on cancer and other nonvascular outcomes of adding ezetimibe to simvastatin (which has been shown on its own to be safe in large-scale trials ${ }^{3,4}$ ).

In conclusion, SHARP has randomized 9,438 patients with CKD to receive LDL-lowering therapy or placebo for an average of about 4.4 years. Final follow-up will be completed by August 2010, and the results will be presented by the end of the year. As described above, the chief emphasis will be on the revised outcome of major atherosclerotic events (and not on the protocol-defined outcome of major vascular events), although results will also be presented for the original primary and other efficacy and safety outcomes.

\section{Acknowledgements}

The most important acknowledgement is to the participants in SHARP and to the Local Clinical Centre staff, Regional and National Coordinators, Steering Committee, and Data Monitoring Committee listed in online Appendix B.

\section{Disclosures}

The study was funded by Merck \& Co and by Schering Plough Corporation (who merged in 2009), with additional support from the Australian National Health and Medical Research Council, the British Heart Foundation, and the UK Medical Research Council.

\section{References}

1. Prospective Studies Collaboration. Blood cholesterol and vascular mortality by age, sex, and blood pressure: a meta-analysis of individual data from 61 prospective studies with 55,000 vascular deaths. Lancet 2007;370:1829-39.

2. Chen $Z$, Peto R, Collins R, et al. Serum cholesterol concentration and coronary heart disease in population with low cholesterol concentrations. BMJ 1991;303:276-82.

3. Cholesterol Treatment Trialists' (CTT) Collaborators. Efficacy and safety of cholesterol-lowering treatment: prospective meta-analysis of data from 90,056 participants in 14 randomised trials of statins. Lancet 2005;366:1267-78.

4. Cholesterol Treatment Trialists' (CTT) Collaboration. Efficacy and safety of more intensive LDL-lowering therapy: meta-analysis of individual data from 170,000 participants in 26 randomised trials of statins. Lancet. In press.

5. Foley RN, Parfrey PS, Sarnak MJ. Clinical epidemiology of cardiovascular disease in chronic renal disease. Am J Kidney Dis 1998;32(Suppl 3):S1 12-9.

6. Wanner C, Krane V, Marz W, et al. Atorvastatin in patients with type 2 diabetes mellitus undergoing hemodialysis. N Engl J Med 2005; 353:238-48.

7. Fellström B, Jardine AG, Schmieder RE, et al, for the AURORA Study Group. Rosuvastatin and cardiovascular events in patients undergoing hemodialysis. N Engl J Med 2009;360:1395-407.

8. Baigent $C$, Landray M, Leaper $C$, et al. First United Kingdom Heart and Renal Protection (UK-HARP-I) study: biochemical efficacy and safety of simvastatin and safety of low-dose aspirin in chronic kidney disease. Am J Kidney Dis 2005;45:473-84.

9. Study of the Effectiveness of Additional Reductions in Cholesterol and Homocysteine (SEARCH) Collaborative Group. Randomised comparison of more intensive LDL-lowering therapy with $80 \mathrm{mg}$ versus $20 \mathrm{mg}$ simvastatin daily in 12,064 myocardial infarction survivors. Lancet. In press.

10. Shepherd J. Fibrates and statins in the treatment of hyperlipidaemia: an appraisal of their efficacy and safety. Eur Heart J 1995;16:5-13.

11. Landray $M$, Baigent $C$, Leaper $C$, et al. The second United Kingdom Heart and Renal Protection (UK-HARP-II) Study: a randomized controlled study of the biochemical safety and efficacy of adding ezetimibe to simvastatin as initial therapy among patients with CKD. Am J Kidney Dis 2006;47:385-95.

12. Moorhead JF, El-Nahas M, Chan MK, et al. Lipid nephrotoxicity in chronic progressive glomerular and tubulo-interstitial disease. Lancet 1982;320:1309-11.

13. Tonelli $M$, Isles $C$, Craven $T$, et al. Effect of pravastatin on rate of kidney function loss in people with or at risk for coronary disease. Circulation 2005;112:171-8.

14. Sandhu S, Wiebe N, Fried LF, et al. Statins for improving renal outcomes: a meta-analysis. J Am Soc Nephrol 2006;17:2006-16.

15. Brenner BM, Cooper ME, de Zeeuw D, et al. Effects of losartan on renal and cardiovascular outcomes in patients with type 2 diabetes and nephropathy. N Engl J Med 2001;345:861-9.

16. Lang JM, Buring JE, Rosner B, et al. Estimating the effect of the run-in on the power of the Physicians' Health Study. Stat Med 1991;10: 1585-93. 
17. Pocock SJ, Simon R. Sequential treatment assignment with balancing for prognostic factors in the controlled clinical trial. Biometrics 1975; 31:103-15.

18. Levey AS, Greene T, Kusek JW, et al, the MDRD Study Group. A simplified equation to predict glomerular filtration from serum creatinine. J Am Soc Nephrol 2000;155A:11 [Abstract A0828]

19. National Kidney Foundation. K/DOQI clinical practice guidelines for chronic kidney disease: evaluation, classification, and stratification. Part 4. Definition and classification of stages of chronic kidney disease. Am J Kidney Dis 2002;39(Suppl 1): S46-S75.

20. De Backer G, Ambrosioni E, Borch-Johnsen K, et al. European guidelines on cardiovascular disease prevention in clinical practice. Third Joint Task Force of European and Other Societies on Cardiovascular Disease Prevention in Clinical Practice. Eur Heart J 2003;24:1601-10.

21. Grundy SM, Cleeman J, Merz CNB, et al. Implications of recent trials for the national cholesterol education program adult treatment panel III guidelines. J Am Coll Cardiol 2004;44: 720-32.
22. British Cardiac Society, British Hypertension Society, Diabetes UK, HEART UK, Primary Care Cardiovascular Society, The Stroke Association. JBS 2: Joint British Societies' guidelines on prevention of cardiovascular disease in clinical practice. Heart 2005;91(Suppl 5): $\mathrm{vl-v52.}$

23. European Medicines Agency. ICH Topic E9: note for guidance on statistical principles for clinical trials. Available at: http://www.ema. europa.eu/pdfs/human/ich/036396en.pdf. Last accessed June 18, 2010.

24. Wittes J. On changing a long-term clinical trial midstream. Stat Med 2002;27:2789-95

25. Rossebø AB, Pedersen TR, Boman $K$, et al, for the SEAS Investigators. Intensive lipid lowering with simvastatin and ezetimibe in aortic stenosis. N Engl J Med 2008;359:1343-56.

26. Cannon CP, Giugliano RP, Blazing MA, et al, for the IMPROVE-IT investigators. Rationale and design of IMPROVE-IT (IMProved Reduction of Outcomes: Vytorin Efficacy International Trial). Am Heart J 2008;156:826-32.

27. Peto R, Emberson J, Landray $M$, et al. Analyses of cancer data from three ezetimibe trials. N Engl J Med 2008;359:1357-66. 


\section{Appendix A. Statistical Analysis Plan for SHARP (finalized on August 20, 2010; blind to results by allocated treatment for clinical outcomes)}

\section{Introduction}

In accordance with the guidance provided by ICH-GCP Statistical Principles for Clinical Trials, ${ }^{23}$ checks have been made during the SHARP trial to ensure that statistical power has been maintained and that assumptions underlying the original design remain plausible. Review of the unblinded lipid assays during SHARP showed that the mean LDL cholesterol reduction at 2.5 years (ie, at about the midpoint of the trial) was $33 \mathrm{mg} / \mathrm{dL}(0.85 \mathrm{mmol} / \mathrm{L})$ rather than the anticipated difference of $39 \mathrm{mg} / \mathrm{dL}(1$ $\mathrm{mmol} / \mathrm{L}$ ), and review of blinded data on clinical outcomes showed that about one third of the original protocoldefined primary outcome of major vascular events (defined as cardiac death, MI, any stroke, or any revascularization procedure $)^{28}$ among the CKD patients in SHARP are noncoronary cardiac deaths or hemorrhagic strokes, which have been found in other trials not to be prevented by statin therapy. ${ }^{4}$ Consequently, in October 2009, the Steering Committee decided (blind to the effects of study treatment on clinical outcomes) to make a number of changes in the plans for analyses in order to ensure that SHARP remains sensitive to any benefits on atherosclerotic outcomes that may exist.

The main change was to place the chief emphasis on "major atherosclerotic events," defined as the combination of coronary death, MI, ischemic stroke or any revascularization procedure (ie, excluding noncoronary cardiac deaths and strokes confirmed to be hemorrhagic) rather than on major vascular events. Consequently, although an analysis of major vascular events will be provided, the chief emphasis will be on the analyses of major atherosclerotic events among all of the patients randomized to ezetimibe/simvastatin versus placebo at any time point (ie, Arm 2 plus 3b vs Arm 1 plus $3 a$, see Figure 1 of the main article). This should help to reduce the possibility of a false negative result by ensuring that a potential beneficial effect on atherosclerotic outcomes is not diluted by a lack of benefit on nonatherosclerotic components.

Comparisons of ezetimibe/simvastatin versus placebo. The prespecified comparisons involve "intention-to-treat" analyses among all of patients ever randomized to ezetimibe/simvastatin versus all patients allocated to placebo, with stratification by whether patients were initially allocated simvastatin for 1 year (Arm 3b vs Arm 3a) or not (Arm 2 vs Arm 1).

Key outcome. The chief emphasis will be on the effects of ezetimibe/simvastatin on the overall incidence of first major atherosclerotic event (ie, coronary death, MI, ischemic stroke, or any revascularization procedure).
Subsidiary outcomes. In support of the analyses of major atherosclerotic events, analyses will be conducted of:

- the original protocol-defined primary outcome of major vascular events (ie, cardiac death, MI, any stroke, or any revascularization), which will also be analysed separately (as in the original protocol) for Arm 2 versus Arm 1;

- the separate components of major atherosclerotic events:

o major coronary events (coronary death or nonfatal MI)

$\circ$ ischemic stroke

○ coronary or noncoronary revascularization (excluding dialysis access procedures)

The main renal outcome will be end-stage renal disease, which is defined as commencement of longterm dialysis or transplantation among patients not on dialysis at the time of randomization to ezetimibe/ simvastatin versus placebo.

Tertiary outcomes and comparisons. It is not anticipated that SHARP will have good power to explore subgroup effects reliably, but tertiary comparisons will assess whether there is definite evidence of variations in the effects of ezetimibe/simvastatin on major atherosclerotic events in different subgroups, based on characteristics at the time of randomization to ezetimibe/ simvastatin versus placebo:

- patients who were receiving dialysis and those who were not

- patients with evidence of pre-existing atherosclerotic disease, including: coronary disease (ie, angina); peripheral arterial disease; cerebrovascular disease; at least one of these 3 conditions; none of them

- diabetes and no diabetes

- men and women

- age: 40 to 49,50 to 59,60 to $69, \geq 70$

- smokers and nonsmokers

- diastolic blood pressure: $<80,80$ to 89,90 to 99 , $\geq 100 \mathrm{~mm} \mathrm{Hg}$

- systolic blood pressure: $<140,140$ to 159,160 to 179 , $\geq 180 \mathrm{~mm} \mathrm{Hg}$

- approximate tertiles of lipid parameters: total cholesterol, LDL-cholesterol, HDL cholesterol, nonHDL cholesterol, triglycerides, apolipoprotein B, apolipoprotein $\mathrm{A}_{1}$

- approximate tertiles of body mass index, waist circumference, hemoglobin, plasma albumin, plasma phosphate

- use of particular drugs, including antiplatelet therapy, oral anticoagulants, angiotensin-converting enzyme inhibitor or angiotensin-receptor blocker, $\beta$-blocker, calcium-channel blocker, diuretic, erythropoietin, sevelamer

Subgroup comparisons of the effects on major atherosclerotic events will also be conducted separately among 
patients who, at the time of their randomization to ezetimibe/simvastatin versus placebo, were:

(i) on dialysis, subdivided by:

- hemodialysis and peritoneal dialysis

(ii) not on dialysis, subdivided by:

- GFR estimated from modified diet and renal disease equation: ${ }^{18} \geq 60,30$ to 59,15 to 29 , $<15 \mathrm{~mL} / \mathrm{min} / 1.73 \mathrm{~m}^{2}$

- approximate tertiles of cystatin C

- normoalbuminuria; microalbuminuria; macroalbuminuria (based on urinary albumin-creatinine ratio)

In addition, subgroup analyses will assess whether the effects on end-stage renal disease of ezetimibe/simvastatin vary according to baseline renal function. Progression to end-stage renal disease is rapid when GFR is already below $15 \mathrm{~mL} / \mathrm{min}$ per $1.73 \mathrm{~m}^{2}$ (ie, Kidney Disease Outcomes Quality Initiative ${ }^{19}$ stage 5 CKD), so even a large proportional reduction in the rate of progression might result in only a short delay before commencing dialysis. By contrast, for patients with stage 3 CKD (ie, GFR $30-60 \mathrm{ml} / \mathrm{min}$ per $1.73 \mathrm{~m}^{2}$ ), a small proportional reduction in the rate of progression might correspond to a delay of some months. Hence, exploratory analyses among patients presenting at different stages of CKD will compare both proportional and absolute effects of allocated treatment on the slope of estimated GFR over time and, separately, on the need for dialysis or transplantation.

Tertiary comparisons will also examine the effects of ezetimibe/simvastatin on:

- mortality, both overall and within particular categories of causes of death: cardiac (coronary, other cardiac), stroke (ischemic, hemorrhagic and unknown type), other vascular, neoplastic, renal, other and unknown causes

- cancers, subdivided by site (in categories previously defined in a published interim analysis of SHARP cancers, ${ }^{27}$ with appropriate statistical adjustment for multiplicity), and excluding any recurrences of cancers known to be present prior to randomization to ezetimibe/simvastatin

- stroke, both overall and subtypes (ischemic, hemorrhagic, and unknown)

- transient ischemic attacks

- hospital admission for angina and, separately, for heart failure

- development of diabetes among patients who were not known to have it at the time of randomization to ezetimibe/simvastatin

- revision of vascular access for dialysis

- end-stage renal disease or death from any cause and, separately, doubling of plasma creatinine or end- stage renal disease (among those not on dialysis at the time of randomization to ezetimibe/simvastatin).

Additional safety outcomes. In addition to assessing the effects of allocation to ezetimibe/simvastatin on the efficacy and safety outcomes listed above, assessments will be made on:

- muscle-related outcomes:

$\circ$ muscle pain or weakness

$\circ$ elevations of creatine kinase: $>5$ but $\leq 10 \times \mathrm{ULN}$, $>10$ and $\leq 40 \times \mathrm{ULN}$, and $>40 \times \mathrm{ULN}$; subdivided into those: without symptoms, with symptoms but no evidence of end-organ damage, with symptoms and evidence of end-organ damage, with symptoms among dialysis patients (when end-organ damage cannot be assessed)

- Liver-related outcomes:

○ hepatitis, subdivided into: infective (definite evidence of an infective cause), noninfective (definite evidence of a non-infective cause), no cause identified (eg, negative viral serology or no serology available)

$\circ$ persistently elevated liver transaminases (at least 2 consecutive alanine or aspartate transaminase $>3 \times$ ULN without other indication of hepatitis)

- complications of gallstones: acute pancreatitis with gallstones; cholelithiasis requiring hospital admission; other complications of gallstones

- pancreatitis (without gallstones): acute pancreatitis; chronic pancreatitis.

\section{Details of analyses}

Analysis of efficacy and safety outcomes. The analyses will involve comparisons of ezetimibe/simvastatin versus placebo during the period for which patients were scheduled to take study medication, irrespective of compliance (ie, "intention-to-treat" analyses ${ }^{29,30}$ ). Analyses will be based on the first relevant un-refuted event, that is, an event of a particular type will be included in an analysis provided that it has either been confirmed or has not been refuted during the adjudication process. In particular, outcomes that involve MI will include definite, probable and possible cases.

Time-to-event analyses will use log-rank methods ${ }^{29,30}$ to calculate average event rate ratios, confidence intervals, and two-sided $P$ values. All analyses will be stratified by whether patients were originally randomized to ezetimibe/simvastatin versus placebo (Arm 2 vs Arm 1) or were re-randomized after about 1 year on allocated simvastatin (Arm 3) to ezetimibe/simvastatin versus placebo (Arm 3b vs Arm 3a). Log-rank observed (O) minus expected (E) values and their variances will be calculated for each of the two strata, and the overall logrank statistic derived as the sum of the log-rank statistics for the 2 strata. The variance for the overall log-rank statistic is the sum of the variances of the log rank (O-E) 
for each stratum. The overall log rank (O-E) and its variance will be used to derive the stratified odds ratio, its confidence interval, and 2 -sided $P$ value. ${ }^{29,30}$

Tests for heterogeneity of effects. The large number of major atherosclerotic events expected in this study may allow direct assessment of the effects of treatment in some subcategories of patient (eg, baseline levels of LDL cholesterol). However, when a number of different subgroups are considered, chance alone may lead to there being no apparent effect in several small subgroups in which the effect of treatment really is about the same as is observed overall. In such circumstances, "lack of direct evidence of benefit" is not good "evidence of lack of benefit," and clearly significant overall results would provide strong indirect evidence of benefit in some small subgroups where the results, if considered in isolation, are not conventionally significant (or, even, perhaps, adverse). ${ }^{29-31}$ Hence, unless the proportional effect in some specific subcategory is clearly different from that observed overall, the effect in that subcategory is likely to be best estimated indirectly by applying the proportional effect observed among all patients in the trial to the absolute risk of the event observed among control patients in that category. ${ }^{29,30}$ Tests for heterogeneity of the proportional effect on particular outcomes in specific subgroups will be used (with allowance for multiple comparisons and other differences between subgroups) to determine whether the effects in those subgroups are clearly different from the overall effect. ${ }^{29,30}$ If, however, such subgroups can be arranged in some meaningful order (eg, baseline renal function) then assessment of any linear trend in the proportional effects on outcome will be made instead. Baseline status of patients will be as measured at the time of their randomization to ezetimibe/ simvastatin versus placebo (so, for patients in arm 3, their baseline characteristics will, wherever possible, be updated to reflect their status when re-randomized).

Allowance for multiplicity of comparisons. The key analysis of major atherosclerotic events and the subsidiary analysis of major vascular events (the original primary outcome) will be performed without adjustment for multiplicity. The subsidiary analyses of the separate components of major atherosclerotic events will be assessed with appropriate adjustment for multiplicity using the Hochberg procedure. ${ }^{32}$ For the interpretation of tertiary comparisons, allowance will be made for multiple hypothesis testing, ${ }^{29,30}$ taking into account the nature of events (including timing, duration and severity) and evidence from other studies. In addition to the prespecified comparisons, many other analyses will be performed, with due allowance for their exploratory and, perhaps, data-dependent nature. Conventionally, 2-sided $P$ values $<.05$ are described as "significant." However, the larger the number of events on which a comparison is based and the more extreme the $P$ value (or, analogously, the further the lower limit of the confidence limit is from the null hypothesis) after allowance has been made for the nature of the particular comparison (ie, primary, secondary or tertiary; prespecified or exploratory), the more reliable the comparison and, hence, the more definite any finding should be considered.

Analyses of biochemical efficacy. Biochemical efficacy samples were scheduled to be taken from $10 \%$ of the study population at their 1- and 4-year follow-up visits and from all patients at their 2.5-year visits. Absolute changes in plasma lipids between randomization and follow-up are calculated for each patient, with zero change assigned to anyone selected for blood sampling who was alive at the time of the follow-up assessment but failed to provide a sample for any reason (since such patients are likely to have discontinued treatment). Student's $t$ test will be used to compare the mean changes observed in the ezetimibe/simvastatin and placebo groups.

Health economic analyses. For the purposes of within-trial economic analyses and assessment of healthcare resource utilization, a summary of all major vascular events, cardiac events, revascularization procedures (coronary or noncoronary), deaths, onset of end-stage renal disease, hospital admission for angina, and hospital admission for heart failure will be derived. A separate analysis plan for determining the costing of these events, sensitivity analyses, subgroup analyses, variance estimation, and statistical testing for treatment comparisons will be developed. In addition to the within-trial analyses, survival analyses will be used to generate a prediction model for the projection of events beyond the trial treatment period and evaluation of the lifetime costeffectiveness of ezetimibe/simvastatin.

\section{Appendix B. Trial organization}

Writing Committee: C Baigent, M Landray, C Reith, T Dasgupta, J Emberson, W Herrington, D Lewis, M Mafham, R Collins.

Steering Committee: R Collins (chair), C Baigent (study coordinator and chief investigator), M Landray (clinical coordinator), C Bray, Y Chen (administrative coordinators), A Baxter, A Young (computing coordinators), M Hill (director, central laboratory), C Knott (nursing coordinator), A Cass, B Feldt-Rasmussen, B Fellström, R Grobbee, C Grönhagen-Riska, M Haas, H Holdaas, LS Hooi, L Jiang, B Kasiske, U Krairittichai, A Levin, Z Massy, V Tesar, R Walker, C Wanner, D Wheeler, A Wiecek (national coordinators), T Dasgupta, D Lewis, M Mafham, W Majoni, C Reith (clinical support), D Simpson (lay member), J Strony, T Musliner (Merck Schering Plough, nonvoting), L Agodoa, J Armitage, Z Chen, J Craig, D de Zeeuw, M Gaziano, R Grimm, V Krane, B Neal, V Ophascharoensuk, T Pedersen, P Sleight, J Tobert, C Tomson. 
Independent Data Monitoring Committee: P Sandercock (Chair); C Hill, A Keech, P Whelton, S Yusuf; nonvoting statisticians to the DMC: R Peto, J Emberson, S Parish.

International Coordinating Centre, CTSU, University of Oxford

Senior management team: C Baigent, C Bray, C Knott, M Landray; Administration: T Bahu, E Booth-Davey, A Brewster, F Yau, E Denis, K Frederick, D Haywood, J Heineman, S Howard, K Jayne, Z Madgwick, S Michell, K Murphy, L Ning, J Nolan, M Nunn, J Roberts,

M Wickman; Clinical support and outcome adjudication: L Bowman, R Bulbulia, T Dasgupta, R Haynes, W Herrington, D Lewis, M Mafham, W Majoni, K Rahimi, N Rahman, C Reith; Computing: R Ait-Sadi, I Barton, A Baxter, A Young, W Zhu; Laboratory: M Hill, S Clark, K Kourellias, M Radley; Monitoring: K Brown, D Worthing; Statistics: J Emberson; Validation: G Coates, B Goodenough, N Lucas.

Regional and National Coordination

Australia: The George Institute for International Health, Sydney: B Neal, A Carreras, A Cass, R Currie, O Donaldson, E Fjalling, M Gallagher, K Gibson, J Goddard, J Healy, L Hones, M Jardine, I Kwong, C Lee, M Merai, S Murray, V Perkovic, A Rendina.

Austria: Allgemeines Krankenhaus Wien, Vienna: M Haas.

Canada: St Paul's Hospital, Vancouver: A Levin; London Health Sciences Centre, Ontario: K Gallo; Penticton Regional Hospital: S Caron; St Paul's Hospital, Vancouver: K Carlson, K Foley, S Matzek, L Mewhort, S O'Donoghue, A Perel-Winkler, T Terins.

China: Fuwai-Oxford Collaborative Centre for Cardiovascular Health, Beijing: L Jiang; CTSU, University of Oxford: Y Chen, Z Chen, Q Nie, H Yu; Fuwai-Oxford Collaborative Centre for Cardiovascular Health, Beijing: L Ge, D Hao, L Li, X Pang, X Wei, G Yan.

Czech Republic: Charles University, Prague: V Tesar, V Certikova Chabova.

Denmark: H:S Rigshospitalet, København $\varnothing$ : B FeldtRasmussen; Smerud Medical Research Denmark, Brøndby: H Holst, T Mølvadgaard, D Munksgaard.

Finland: Helsinki University Hospital: C Grönhagen-Riska; Smerud Medical Research Finland, Espoo: Y Peltonen.

France: Centre de Recherche Clinique, et Services de Pharmacologie Clinique et de Néphrologie, Amiens: Z Massy; Centre de Recherche Clinique, et Service de Pharmacologie Clinique, Amiens: S Liabeuf; Direction de la Recherche clinique, Amiens: C Lebel, L Ouabou.

Germany: Universitätsklinikum Würzburg and Zentrale für Klinische Studien am Klinikum: B Bauer, K Bergmann, M Beusch, D Cavitt, C Drechsler, I Dulau, K Hügen, V
Krane, S Kempf, B Kuchenmeister, S Küllmer, V Pscheidl, D Schmiedeke, M Schwarz, K Speerschneider, B Stahl, C Wanner.

Malaysia: Hospital Sultanah Aminah, Johor Bahru: L S Hooi; Clinical Research Centre, Kuala Lumpur: BC Lim, Nadia H, Zishareena M F, S Vasuthavan; Klinsel Sdn Bhd, Kuala Lumpur: AT Ganesapillai, S Yuen.

Netherlands: Julius Centre for Health Services and Primary Care, Utrecht: D Grobbee, I Bobbink, K Groot, I Sikking; University Medical Center Groningen, University of Groningen: D de Zeeuw.

New Zealand: Dunedin Hospital: R Walker; The George Institute for International Health, Sydney: J Raley.

Norway: Rikshospitalet Universitetssykehus, Oslo: H Holdaas; Smerud Medical Research Norway, Oslo: M Colban, K Smerud, N Trygg, E Waagaard, H Westad.

Poland: Fundacja Dializa by Katedra i Klinika Nefrologii Endokrynologii i Ch, Katowice: A Wiecek, S Rotkegel, U Spiechowicz; Smerud Medical Research Poland, Warsaw: M Domoradzka, M Gawłowska.

Sweden: Njurmedicin, Medicincentrum, Uppsala: B Fellström; Smerud Medical Research Sweden, Uppsala: A Flygar, I Ödmark, A Pettersson.

Thailand: Maharaj Nakorn Chiang Mai Hospital: V Ophascharoensuk; Rajavithi Hospital, Bangkok: U Krairittichai.

United Kingdom: Royal Free Hospital, London: D Wheeler; Addenbrokes Hospital, Cambridge: S Blackwood; CTSU, University of Oxford: J Barclay, J Benham, R Brown, L Cureton, D Jackson, I Kennedy, C Leaper, A Taylor, C Winter, C Wise; Leighton Hospital, Crewe: M Nash; Macclesfield Hospital: A Taylor Bennett; Princess Royal Hospital, Telford: D Donaldson; Queen Margaret Hospital, Dunfermline: K Chalmers; Southmead Hospital, Bristol: H Corderoy.

USA: Hennepin County Medical Centre, Minneapolis: B Kasiske; Berman Center for Clinical Research, Minneapolis: M Bartkoske, C Bjerk, A Camarena, R Grimm, L Herskovitz, C Heuer, J Levin, R Robinson, B Wicklund; Boston VAMC: D Bentzel, S Cohen, C Costa, M Gaziano, R Scranton.

Local Clinical Centres

Australia

Albury Base Hospital: R Auwardt, M Boyer, P Cogdell, K Gibson; Alfred Hospital, Melbourne: S Menahem, J Sheldrake; Austin Health, Melbourne: P Mount, M Fraenkel, P Bisscheroux, J Dempester, P Gleeson; Bendigo Health Care Group: G Harris, C Holmes, K Hyett, A Linton; Bundaberg Base Hospital: P Miach, D Booth, L Druce; Cairns Base Hospital: M Mantha, E Borg, S Green, J Killen, Y Lynch; Core Research Group Pty Ltd, Milton: D 
Colquhoun, K Herzig, G Row, J Addison, J Asa, G Beatson, D Calvird, J Edmunds, A Ferreira-Jardim, A Gwynne, D Mackay, L McLoughlin, C Wightwick, L Williams; Fremantle Hospital: P Ferrari, J Barry, S Hodson, W Zakrzewska; Gold Coast Hospital: E Meagher, M Mulcahy, A Parnham; John Hunter Hospital, Newcastle: S Carney, L Garvey, A Gillies, S Hayes; Launceston General Hospital: M Mathew, R Fassett, L Anderson, C Clingeleffer, A Curnock, L Mayne, D Richardson, M Smith, S Smith; Liverpool Hospital: M Suranyi, K Howlin, J Chow, B Cleland, G Rayment, T Spicer, J Wong, M Wong; Melbourne Renal Research Group: D Packham, C Alison, I Fraser, J Mitchell, J Nagle; Monash Medical Centre, Clayton: F Brown, C Ellery, J Monkhouse, J Nandkumar, L Reith-Myers; Nambour General Hospital: N Gray, C Cocks, M Courtney, P Hollett, C Johnston, H Larsen, S Murray, A Pollock, S Stewart, G Styles; Nepean Hospital, Penrith: R Wyndham, M Fanning, W Gibson, S Jackson, M Mannering, E Mercado, R Oliphant, K Sud, N Ubera, C Wood; Peninsula Clinical Research Centre, Queensland: J Karrasch, T Brinkley, K Estensen, A Moroney, J Sutton, R Warren; Pine Rivers, Chermside: D Saltissi, H Jahke, $\mathrm{H}$ Roach, J Saltissi (Cockayne), M Wiederroth O'Brien; Princess Alexandra Hospital, Woolloongabba: D Johnson, V Bali, J Edmunds, M Evans, K Franzen, S Halbish, J Helyar, A Martin, D Mudge, K Sonnenburg, J Sudak; Renal Research, Gosford: S Roger, S Almeida, H Andrews, L Bohringer, L Bouwhuis, L Brady, A Carpenter, S Warren; Royal Adelaide Hospital: T Elias, K Bannister, G Chew, J Clarke, R Faull, A Hooper, L Jeffs, A Napier, C Peh, K Pirone, F Skilton; Royal Brisbane Hospital: D Ranganathan, J Best, L Hart, H Healy, C Morgan, S Ratanjee, A Salisbury; Royal Hobart Hospital: M Jose, J Freeman, R Hamilton, G Kirkland, G Read; Royal Melbourne Hospital: R Walker, V Perkovic, H Anderson, K Boekel, M Farrell, A Foreman, K Iliev, E Pedagogos, T Raspudic; Royal North Shore Hospital, St Leonards: C Pollock, B Cooper, J Kesselhut, C Macadam, J Pearse, C Rowland, H Tully; Royal Perth Hospital: A Irish, G Dogra, P Coutts, L Hayes, D Khoo, B Nathoo, K Shakespeare, A Warger; Royal Prince Alfred Hospital, Sydney: A Gillin, J Burman, C George, S Sherwood, P Snelling, C Stevens; Sir Charles Gairdner Hospital, Perth: B Hutchison, G Luxton, J Barry, N Devenny, L Hayes, H Herson, S Pellicano; St George Hospital, Kogarah: J Kelly, J Coutelas, C Garlinge, A McClelland, S Pirabhahar, H Saleh; St Vincent's Hospital, Fitzroy: R Langham, B Englebright (Joseph), M Giang, M Lanteri, K Mullins, C Turner; Sydney Adventist Hospital: P Collett, S Stokoe, K Sutherland, D Talafua; The Canberra Hospital: G Talaulikar, A Clarkson, M Gallagher, C Rees, G Carney, M Falk, D Gracey, A Jadeer, P Johnson, K Karpe, R Singer, G Walters; The Queen Elizabeth Hospital, Adelaide: S McDonald, J Burgess, K Fischer, M Gentgall, M Hockley, D Veitch; The Townsville Hospital: P de Jersey, A Gillam, V Hartig, K Holland, J McArdle, W Washington; Westmead Hospital: G Rangan,
M Mikaheal, P Murie, N Perez, N Punnoose, T Smolonogov, N Taler, G Williams; Wollongong Hospital: C Wen, J Kohlhagen, J Wessels, S Johnson, A Reid, J Ryan, D Taprell.

\section{Austria}

Allgemeines Krankenhaus Wien: M Haas, M Auinger, M Eigner, K Kodras, C Leithner, L Magpantay, C Marterer, R Prager, C Prinz; Klinikum Wels-Grieskirchen: E Seiringer, R Kramar, E Mitter, H Stummvoll, G Dieplinger, Krankenhaus Zell am See: R Wenzel, G Stolz, S Dröse, E Edlinger, E Headlam-Leitner, H Miska, M Then, S Weninger; Landeskrankenhaus Feldkirch: K Lhotta, U Neyer, H Dickie, S Smodek, H Sprenger-Mähr; Universitätsklinik für Innere Medizin Innsbruck: A Rosenkranz, E Zitt, B Mayr, A Schinner.

\section{Canada}

Charles LeMoyne Hospital, Greenfield Park: G Soltys, V Bégin, S Brunet, S Cournoyer, M Gelinas, C Giroux, J Martineau, M Roy, L Savoie; CHUQ-Hotel Dieu de Quebec: M Agharazii, J Blouin, S Desmeules, S Langlois, F Samson; Credit Valley Hospital, Mississauga: G Wong, L Constantini, J Jing, J Malko, C Rivers, D Rochester, C Skilling, A Wadgymar, G Wu; David M Kates Medical Services Inc Kelowna: D Kates, J Husch, M Mantle, L Turri; Eastern Regional Health Authority, Newfoundland: B Barrett, B Curtis, B Greeley, M Hannaford, J Harnett, M Kelly, E Langille, J Morgan, S Murphy; Fraser Health Authority, Vancouver: M Karim, T Arbo, G Carpenito, A Cass, V Chan, G DaRoza, K Foley, M Friesen, D Kraus, S Lam, B Lange, S Minhas, R Starko, S Torng, K Vela; Hôpital du Sacré-Coeur de Montréal: F Madore, P Roy, S Troyanov; Hopital MaisonneuveRosemont, Montréal: A Bonnardeaux, L Lauzon, V Pichette; Kingston General Hospital/Queen's University: K Yeates, K Mahoney, C Myers, R Pilkey; London Health Sciences Centre: L Moist, M Edgar, K Gallo, A House, C Kortas, S Mindorff; OTT Healthcare Inc Scarborough: P Tam, S Chow, J Fung, G Nagai, P Ng, D Rochester, T Sikaneta, R Ting; Penticton Regional Hospital: B Forzley, S Caron, Y Clouatre, S Cooper, H DaCosta, S Granger, S Valley; Regina Qu'Appelle Health Region: S Karunakaran, M Abdulhadi, C Altwasser, S Anderson, L Bergquist; Royal Inland Hospital, Kamloops: C Wijeyesinghe, L Berst; Royal Jubilee Hospital, Victoria: K Horgan, K Coles, T Lotter, L Robson; Royal Victoria Hospital, Montreal: P Barre, J Golden, M Golden, N Tanguay; St Boniface General Hospital, Winnipeg: C Rigatto, S Armstrong, A Fine, B Fontaine, D Friesen, S Henry, M Kraushar, M Reslerova, M Verrelli; St Joseph's Healthcare, Hamilton: C Rabbat, C Clase, G Suva, N Winegard; St Michael's Hospital, Toronto: M Goldstein, S Curvelo, S Donnelly, J Huckle, R Marticorena; St Paul's Hospital, Vancouver: A Levin, C Chan-Yan, A Chiu, L DeLuca, D Flamer, K Foley, J Gill, A Jamal, B Jung, M Kiaii, D Kraus, D Landsberg, S Minhas, 
A Perel-Winkler, N Rozen, P Taylor, K Vela, R Werb; St Paul's Hospital Saskatoon: G Pylypchuk, A Ahmed, J Barton, M Hundseth, J Kappel, I Keindel, J Klassen, S Pylypchuk, M Rindall; Sunnybrook Health Sciences Centre, Toronto: S Tobe, D Naimark, M Agelopoulos, M Chessman, M Hladunewich, N Perkins, S Sainsbury; Thunder Bay Regional Health Sciences Centre:

W McCready, B Adams; University of Alberta Hospital: M Tonelli, S Caldwell, U Kumar, A McMahon, S Nikitin, J Restall, S Treit, Y Wysocki; Vancouver General Hospital: J Duncan, M Copland, J Jastrzebski, P Keown, S Kwan, A Levin, D Rogers, J Shapiro, S Singh, L Sioson, K Yee, C Yeung; Winnipeg Health Sciences Centre: J Zacharias, J Bueti, B Dizon, H Lam, L Miller, M Ross, M Zarrillo.

\section{China}

Baotou Medical College First Affiliated Hospital, Inner Mongolia: Z Li, C Wang, L Liu; General Hospital Of Shanyang Army, PLA of China, Liaoning: M Hong, H Zheng, W Zuo; Inner Mongolia Baogang Staff Hospital: Z Ge, Q Liu, Y Li; Inner Mongolia Baotou City Central Hospital: K Sun, R Zhao; Inner Mongolia Electrical Power Central Hospital: G Sun, F Wang; Inner Mongolia Hulunbeiermeng Hospital: Z Cui; Jilin Province Jilin City Central Hospital: L Liu, F Lou; Jilin Provincial Hospital: Y Du, L Song, H Huang; Lanzhou University Second Affiliated Hospital: Z Song, J Wang, L Zhou; Liaoning Angang Lishan Hospital: R Wu, R Xiao, Q Zhang; Liaoning Provincial People's Hospital: N Duan, N Ju, Z Li; PLA 306 Hospital, Beijing: A Wang, Z Xu, Z Lu; Shangdong Weifang People's Hospital: Y Zhang, L Zhao; Shenyang Fourth People's Hospital: Y Li, C Zhang; The Third Xiangya Hospital of Central South University, Hunan: Z Mo, Y Xie, J Xiong; Wuhan City Central Hospital: J Chen, L Guo, S Zhao.

Czech Republic

Charles University, Prague: M Peiskerova, E Jancova, M Kazderova, L Kobrova; Csl Armady 1076-HDS Eurocare, Usti nad Orlici: P Gorun; FNKV-Fresenius Dialysis Unit, Prague: T Kmentova; Institute for Clinical \& Experimental Medicine IKEM, Prague: M Burgelova, L Lyerova, O Viklicky; Kukucinova-Fresenius Dialysis Unit, Prague: M Berdych; Nemocnice Strakonice-dialyza: Z Nydlova, G Jelinkova, J Moltaš; Nemocnice, Jihlava: T Pauzar, P Knetl, J Cahova, J Simkova, M Zakova; Nusle-HDS Eurocare, Prague: S Vankova, R Safarova; Parallel 50-HDS Eurocare, Prague: M Hruby, R Karlova, V Prikaska, P Sellenberg; Plzen-HDS Eurocare: E Vesela, L Malanova; Sokolov-Fresenius FMC Dialysis Unit: J Vlasak, P Kaprova, D Novakova; Teplice-HDS Eurocare: K Kotherova, M Studenovska.

Denmark

Aalborg Sygehus Syd: J Christensen, J Sølling, M Jepsen, V Kristensen; H:S Rigshospitalet, København Ø: B FeldtRasmussen, H Aerenlund, M Bræmer-Jensen, A Kamper,
S Raaschou; Herlev Hospital: J Heaf, J Dreyer, P Freese, M Holm, M Munch; Hillerød Sygehus: E Gade-Rasmussen, K Bredmose, H Daugaard; Holbæk Sygehus: J Nielsen, M Friedberg, D Jensen, M Munk Plum, K Sølling; Odense Universitetshospital: H Dieperink, L Arp Nielsen, E Friborg, A Gløe-Jakobsen, P Thye Rønn; Roskilde Sygehus: K Rasmussen, C Andersen, A Johansen, L Ødum, O Østergaard, L Pedersen; Sønderborg Sygehus, Odense C: H Dieperink, S Lykkegaard, M Aundal, L Arp Nielsen, S Faureholm Huess, P Freese, E Friborg, A Gløe-Jakobsen; Viborg Sygehus: H Danielsen, J Madsen, M Nyvang.

Finland

Helsinki University Hospital: A Ekstrand, H Boman, J Hartman, A Lipponen, R Lithovius, V Rauta, A Salmela, K Saloranta; Keski-Suomen Central Hospital, Internal Medicine Clinic, Jyväskylä: T Forslund, P Koskiaho; Pohjois-Karjala Central Hospital, Internal Medicine Department, Joensuu: K Jääskeläinen, M Kanninen; Satakunta Central Hospital, Pori: K Laine, M Asola, J Huhti, M Pentti; Turku University Hospital: K Metsärinne, M Heiro, N Koivuviita, M Saarinen, R Tertti.

France

Amiens: Z Massy, G Choukroun, A Fournier, S Liabeuf, L Ouabou; Besancon: D Ducloux, F Marechal, D Simula Faivre; Bordeaux: C Combe, M Douillet, T Lamblot, H Nardi, B Vendrely; Brest: B Bourbigot, S Ferlandin; Grenoble: P Zaoui, C Jouet; Harfleur-Clinic du Petit Colmoulins: S Geffroy-Guiberteau, L Bugnazet; Limoges: J Aldigier, C El Hamel-Belili, S Giraud; Marseille: B Dussol, Y Berland, M Chollet, H Sichez; Montpellier: J Cristol, B Canaud, M Morena, A Rodriguez; Nancy: M Kessler, B Mizejewski, B Risse; Paris-Clinique du Landy: P Urena Torres, M A Bou-Bekr, C Arezki, P Ras el Qdim; PerpignanHopital Saint Jean: C Vela, F Borsato, A Talairach; PessacClinique Saint Martin: M Normand, V Normand; Reims: P Rieu, B Gauthier, C Vigneron-Foy, A Wolak; VannesCentre de Dialyse ECHO: V Menoyo, L Alos; Vienne: A Caillette-Beaudoin, V Berger.

\section{Germany}

Ambulante Dialyse/Gemeinschaftspraxis Augsburg: S Al-Sarraf, I Konnerth, C Urban; Brüderkrankenhaus Trier: S Weiner, W Boesken, E Jochum, C Kiefer, A Wagner; Deutsche Klinik für Diagnostik GmbH Wiesbaden: B Krumme, J Böhler, B Bonow, U Hohenstatt, T Mettang, A Röckel; Dialyse Reutlingen: J Langanke, H Lipponer, G Dunschen-Weimar, R Dunst, E Hübel; Dialyse Rhein-Ahr, Bad Neuenahr-Ahrweiler: R Petrik, R Rengel, M Schmidgen; Dialysepraxis Altötting: H Mayr, C Garschhammer, S Weirauch; Dialysepraxis Arnstadt: H Anger, T Gööck, A Mai; Dialysepraxis Leipzig: I Bast, C Süptitz; Dialysepraxis Meiningen: B Iwig, K Florschütz, R Haßelbacher, G Sauerbrey, S Delrieux, S Rau; Dialysepraxis Seehausen: M Poley, R Laux, O Schönfelder; Dialysezentrum/Gemeinschaftspraxis Heilbronn: 
G Kunowski, G Fuchs, K Hoffmann, R Schürger; Dialysezentrum Bad Godesberg, Bonn: K Brensing, Z Güven, C Immenkamp, C Kottmann, H Schmitt; Dialysezentrum Bad Laasphe: M Schulz, P Arnold, R Knaup, H Schneider, H Siemsen; Dialysezentrum Bad Malente: P Pyriki, F Körkemeyer, R Pyriki, A Siebrecht; Dialysezentrum Bovenden: E Schulz, A Krumwiede, D Kruse, S Lücke; Dialysezentrum Darmstadt: H Keim, H Fink, S Fischer, A Klingbeil, K Kuhlmei, N OrtweinHorn; Dialysezentrum Dormagen: L Merker, B Bayer, K Benamar, S Emmert, E Floten, K Holzheuer, M Lummer, E Ossendorf, M Scholz; Dialysezentrum Halberstadt: M Oppitz, L Georgiew, C Tripps, M Wendehake; Dialysezentrum Heiligenstadt: D Lange, V Pingel; Dialysezentrum Jacobistraße Düsseldorf: M Brause, W Schanze, E Duygulu; Dialysezentrum Karlstraße Düsseldorf: F Dellanna, S Heinemann-Nieberding, C Stürmer, K Wieczorek, O Zarga; Dialysezentrum Küllmer, Kirchhain: B Küllmer, S Küllmer, M Akin, M Gondolf, S Schütterle; Dialysezentrum Pirmasens \& Kusel: G Walker, R Bertsch, M Seul, J Allendorff, R Siehler, S Stemmler; Dialysezentrum Rüsselsheim: M Baldus, A Adler, S Härter, W Würmell; Dialysezentrum Saarlouis: M Möller, C Hame, M Müller, M Schreiber, C Schürfeld; Dialysezentrum Schöneberg-Tempelhof Berlin: M Millington-Herrmann, A Benschneider, J Gaffal, U Sprünken; Dialysezentrum Wilhelmshaven: M Bohling,

S Wunderlich; Dialysezentrum Würzburg: L Schramm, C Kollenbrath, K Netzer, T Sieber, J Zimmermann; Gemeinschaftspraxis am Sophienhof Kiel: M Bellersen, M Uerkvitz; Gemeinschaftspraxis Kiel: T David-Walek, B Hauschildt, G Leimenstoll; Gemeinschaftspraxis Langenhagen: G Lonnemann, M Hilfenhaus, C Benedetto, S Stöckmann; Gemeinschaftspraxis Marktredwitz \& Selb: P Ichtiaris, A Jungmann, K Neumeier, A Stoof; Gemeinschaftspraxis Nürnberg: K Böhmer, A Kirpal, A Knogl; Gemeinschaftspraxis Schloß Holte-Stukenbrock: F Flege, K Franke, P Groth, E Parensen; Internistische Gemeinschaftspraxis Alzey: M Böckmann, P Przyklenk; Internistische Gemeinschaftspraxis und Dialyse Friedrichshafen: L Piazolo, L Thinius-Jaudas, A Versen; Internistische Praxisklinik Kempten: R Hettich, R Arendt, K Geiger, H Hoppe; Johannes Gutenberg-Universität Mainz: A Schwarting, T Beyer, J Faust, A Hazenbiller, S Tschirner; KfH Nierenzentrum Bamberg: C Grupp, O Dorsch, M Eigner-Schmidtchen, K Michler, J Roth, S Schramm, G Waldmüller; KfH Nierenzentrum Bayreuth: B Riedl, H Vögele-Dirks, J Linz; KfH Nierenzentrum Coburg: P Biggar, H Hennemann, G Bauer, J Buchholz, P Fischer; KfH Nierenzentrum Donauwörth: W Bihlmaier, A Baumann, B Peichl; KfH Nierenzentrum Eberswalde: S Röser, S Ludewig, M Ricksgers, M Szendzielorz; KfH Nierenzentrum Frankfurt/Oder: A Baus, K Baust, P Schaller, G Schnellbacher, S Sörensen; KfH Nierenzentrum Fürth: B Büschges-Seraphin, L Hauenstein, B Hofmann, J Nikolay; KfH Nierenzentrum Köln-Mer- heim: F Merkel, M Nebel, J Petersen, S Schweb; KfH Nierenzentrum Kulmbach: H Zeißler, K Baumhackel, A Krauß; KfH Nierenzentrum Marl: R Schäfer, A Pastor, B Zielinski; KfH Nierenzentrum Trier: H Strauß, H Theis; KfH Nierenzentrum Weißenburg: K Burkhardt, M Heckel, K Hussendörfer; KfH Nierenzentrum Würzburg: U Bahner, M Brandl, B Hammerl-Kraus, D Herrmann, H Kramer, H Baudenbacher, C Blaser, G Buschmann, G Eckert, H Ehrich, K Hofmann, U Hüller; Klinikum der Johann Wolfgang Goethe Universität Frankfurt: H Geiger, B Becker, S Hoischen, C Bartel, J Hennig, N Obermüller, C Schulte; Klinikum der LMU München: M Fischereder, F Burchardi, H Rupprecht, S Weidner, H Anders, L Andriaccio, S Lederer, G Ricken, C Straßer; Klinikum Mannheim der Universität Heidelberg, Mannheim: A Lammert, W Schmitt, F van der Woude, B Langhäuser; Martin-Luther-Universität Halle: S Markau, B Osten, D Thiemicke, O Dorligschaw, M Weickert; Medizinische Universitätsklinik Würzburg: V Krane, F Breunig, G Denninger, S Osiek, W Rebstöck, P Schulz, F Swoboda, B Bauer, K Bergmann, D Cavitt, D De Cicco, C Drechsler, I Dulau, J Harlos, B Kuchenmeister, A Lebert, V Pscheidl, M Riegel, T Schmiedeke, K Speerschneider, B Stahl; Nephrologische Gemeinschaftspraxis Hamm-Heessen: U Hoffmann, M Nölle, P Jankrift, H Pfleiderer, J Witta, B Wittler; Nephrologische Gemeinschaftspraxis im Heidering Hannover: J Lüth, H Dumann, U Häbel, A Torp; Nephrologische Gemeinschaftspraxis Rostock: D Sehland, M Tie $\beta$, C Etzold, A Friederiszik; Nephrologische Praxis \& Dialysezentrum Elsenfeld: A Morgenroth, A Dybala, A Suffel; Nephrologische Praxis Berlin-Köpenick: T Leimbach, J Kron, S Sauer; Nephrologische Praxis Dr Meyer Bad Nauheim: T Meyer, M Meyer; Nephrologische Praxis und Dialyse Oldenburg: U Lammers, J Bekman, S Holtz, B Kausler-Book, S Stobbe; Nephrologisches Zentrum Emsland, Lingen: H Hohage, M Heck, F Schulte, U Welling, M Zeh; Nephrologisches Zentrum Pforzheim: J Seyfried, T de Heij, A Menzinger; Nephrologisches Zentrum Villingen-Schwenningen: T Weinreich, M Hopf; Nephrologisches Zentrum Weißensee Berlin: J Groll, K Kammholz, K Peters, G Schwietzer; PHV-Dialysezentrum Hildesheim: B Kreft, U Weibchen; Praxis Dr André Voßkühler Bottrop: A Voßkühler, M Hollenbeck, K Klaue, E Rzepucha, K Sperling; Praxis für Nierenkrankheiten und Dialyse Berlin: W Seeger, J Weyer, C Heine, P Kirste, B Zemann; Robert-Bosch-Krankenhaus Stuttgart: D Alscher, D Rumpf, B Wullen, A Bengel, B Friedrich, T Kirschner, U Knödler, C Machleidt, K Niederstrasser, E Noack, J Wilhelm; St Johannes-Hospital Dortmund: H Heuer, J Dulea, R Piolot, M Rudke, G Treinen, B Elberg, J Hanke, T Nitschke, C Rosendahl, A Schmitz, H Schneider; St Josefs-Hospital Cloppenburg: J Schrader, A Kulschewski, C Lübcke, F Hammersen, S Lüders, U Venneklaas; Universitätsklinikum Aachen: A Mühlfeld, F Arabi Al-Khanne, M Ketteler, D Politt, C Schuster, 
F Eitner, U Göretz, S Heidenreich, U Janssen, A Kranz, E Moormann, B Schneider, W Weber; Universitätsklinikum Charite, Campus Virchow-Klinikum, Berlin: U Frei, T Jovanovic, H Asmus, S Canaan-Kühl, L Pannier, S Petersen, M Plüer, E Schaeffner, C Schäfer, S Warncke; Universitätsklinikum Erlangen-Nürnberg: R Schmieder, C Donhauser, B Schulze; Universitätsklinikum Göttingen: M Koziolek, W Bechtel, B Kurz, F Strutz, C Bramlage, S Dreyer, E Mommeyer, J Niemann, A Scheel, I TrochePolzien, F Weber; Universitätsklinikum Homburg/Saar: G Heine, M Girndt, F Lizzi, K Rogacev; Universitätsklinikum Leipzig: T Lindner, H Achenbach, K Peschel, J Beige, S Jentho, C Kreyßig, K Prill; Universitätsklinikum Schleswig-Holstein, Campus Kiel: L Renders, M Scholz, J Walcher, S Cerny, A Fülbier, H Kristen; Universitätsklinikum Schleswig-Holstein, Campus Lübeck: M Nitschke, J Kramer, P Marek, M Meier, J Schlieter; Universitätsklinikum Tübingen: N Heyne, F Bachmann, M Faber, K Klipp, U Küstner, T Risler; Westpfalz-Klinikum Kaiserslautern: T Rath, T Ruf, D Budiman, C Seidel, S Weik.

\section{Malaysia}

Hospital Ipoh: S M Teo, L Y Lee, Azizah H, Faridunishah S A, S M Foo, K W Go; Hospital Kuala Lumpur: Ghazali A, K H Koh, Zaki M, H S Wong, S Bavanandan, L M Boey, Lily M, S L Wong, Rosnawati Y; Hospital Kuala Trengganu: Zawawi N, Azimawati A, Hindun A, Hasnah J; Hospital Melaka: Korina R, Yunaidah A, Noraidah P; Hospital Pulau Pinang: L M Ong, Noor Asma A, Y F Liew, Rozina G, Y H Cheong, A H Ang, Dayang J, L S Lim; Hospital Raja Perempuan Zainab II, Kota Bharu, Kelantan: Sukeri M, Ramli S, Zulkifli M, Wan Mahmood W K; Hospital Selayang: H S Wong, B L Goh, Ghazali A, Sarifah B, B C Bee, Lily M, C Ramasamy, Ruszarimah S; Hospital Sultanah Aminah, Johor Bahru: L S Hooi, W J Liu, Razali O, Haslinah S; Hospital Taiping: I Vaithilingam, Jaaini A, Faridah L; Hospital Tengku Ampuan Afzan, Kuantan, Pahang: Ramli S, K H Ng, P Krishnan, Rosnah A A, Nor Azizah A S, C C Tam, S H Tan; Hospital Tengku Ampuan Rahimah, Selangor: C C Tan, Shahnaz F K, Wazir H, P Munusamy; Hospital Tuanku Jafa'ar, Seremban: Wan Shaariah M Y, T F Chew, Fuziah Z; Hospital Umum Sarawak: C H H Tan, Maria L, Javelin P; University Malaya Medical Centre, Kuala Lumpur: S K Lim, Nazatul S B, L P Engkasan, S Y Tan, M G Wong, Julita A A, B B Ang, S Krishnan, W W T Seet, S K Liew, T C Keng.

Netherlands

Diakonessenhuis Zeist/Utrecht: T Tobé, M Deelen, I Klaassen; Laurentius Ziekenhuis: W Grave, M Emmen; Martini Ziekenhuis: W Janssen, W Bossen, B Elzinga, A van der Velden; Medisch Centrum Leeuwarden:

M Hemmelder, M Slagman, F Waanders; Sint Gemini Ziekenhuis: P Viergever, I Boerema; Sint Lucas Andreas Ziekenhuis: B Potter van Loon, B Muthert; St Antonius Ziekenhuis: T Geers, N Schollaert, I van Weverwijk, P Veen; Twenteborg Ziekenhuis: A Woittiez,
J Krikken, A Kwakernaak, F Visser; University Medical Centre Groningen: G Navis, F Hoekstra, J Krikken, A Kwakernaak, M Slagman, F Visser, F Waanders.

New Zealand

Auckland City Hospital: L Williams, S Hawkins; Christchurch Public Hospital: D McGregor, J Usher; Dunedin Hospital: R Walker, R MacGinley, J Schollum, G Ellis; Middlemore Hospital, Auckland: D Voss, J Rosman, M Upjohn; Palmerston North-MidCentral Health: N Panlilio, K Madhan, Y Li, V Naicker; Taranaki Base Hospital, New Plymouth: N Panlilio, K Madhan, E Anderson, M Bushell, N Lumb, B Pepperell; Waikato Hospital: P Sizeland, S Hayett, N Sullivan, C Tuffery; Wellington Hospital: A Macdonald, T Ostapowicz.

Norway

Dr Terje Wessel-Aas: T Wessel-Aas, H Wessel-Aas; Nordlandssykehuset HF: E Bjørbæk, R Bjørbæk; St Olavs Hospital: I Simsø, C Øien; Stavanger Universitetssykehus: H Bergrem, S Espedal; Sykehuset Innlandet Lillehammer: J Kronborg, K Solbakken; Sykehuset Levanger: J Rocke, O Aakervik, V Haugen; Sykehuset Østfold: T Eide, J Berglund, W Løland, T Schei, C Strømsæther, H Willadsen; Sykehuset Telemark: P Lyngdal, A Vad; Ullevål Universitetssykehus: B Waldum, G Frøslid, C Roaldsnes, D Rustad, P Söderblom; Universitetssykehuset Nord-Norge HF: B Eriksen, E Hanssen, J Julsrud, U Mathisen, M Pedersen, M Rumsfeld, I Toft; Vestre Viken HF Kongsberg Sykehus: K Berget, K Landsverk, G Tveiten, H Wamstad.

Poland

Akademicki Szpital Kliniczny, Wroclaw: M Klinger, M Krajewska, T Golebiowski, M Kusztal; Fundacja Dializa by Katedra i Klinika Nefrologii Endokrynologii i Chorob, Katowice: A Więcek, S Rotkegel, U Spiechowicz-Zaton; SP Szpital Kliniczny nr 1-Uniwersyteckie Centrum Kliniczne AM, Gdansk: B Rutkowski, M Renke, L Tylicki; SP Szpital Kliniczny nr 2 AM, Poznan: S Czekalski, L Koziol, M Wanic-Kossowska, A Wasik-Olejnik; SP ZOZ Uniwersytecki Szpital Kliniczny nr 1 Uniwersytetu Medycznego w Lodzi: M Nowicki, P Dryja, I Kurnatowska, A Zawiasa; Szpital Kliniczny Dzieciatka Jezus, Centrum Leczenia Obrazen, Warszawa: M Ciszek, M Gomólka; Wojewódzki Szpital Specjalistyczny in Bialystok: M Mysliwiec, S Brzósko, M Mazerska; Wojewódzki Szpital Specjalistyczny in Wroclaw: Z Hruby, K Koscielniak, M Stanek-Piotrowska; Wojewódzki Szpital Specjalistyczny nr 4, Bytom: J Mesjasz, R Rudka, M Barański, J Mesjasz; Wojewódzki Szpital Specjalistyczny nr 5, Sosnowiec: J Jupowiecki, D Klein; Wojewódzki Szpital Zespolony, Plock: M Switalski, M Kuriga, M Ostrowski.

Sweden

Akademiska Sjukhuset, Uppsala: B Fellström, A Lidman, T Linde, K Waltersson; Centralsjukhuset Karlstad: L Weiss, G Andersson, C Lindell, G Welander; Danderyds 
Sjukhus, Stockholm: S Jacobson, P Edensjö, J Wallin; Falu Lasarett: M Linder, M Karsberg, K Hellgren, I Lönn; Länssjukhuset Ryhov, Jönköping: C Frisenette-Fich, A Johansson, A Lundström, N Mauritz, A Ståhl-Nilsson, N Tobafard; Mälarsjukhuset, Eskilstuna: O Hellberg, E Ejemar, N von Schmalensee; Mora Lasarett: T Gunne, A Eriksson, S Östberg, C Svensson; Norra Älvsborgs Länssjukhus, Trollhättan: H Mulec, A Jacobsson, M Karlsson, L Önnermalm; Nyköpings Lasarett: S Osagie, U Ekengren, M Larsson; Östersunds Sjukhus, Östersund: K Lindberger, A Olofsson; Sahlgrenska Universitetssjukhuset, Göteborg: O Samuelsson, L Beagan, H Dezfoolian, M Just, L Örtegren, A Saeed, U Strand; Skaraborgs Sjukhus, Skövde: B Ramsauer, D Hultström, K Nordlinder, I Sundberg; Universitetssjukhuset i Lund: B Öqvist, C Green; Universitetssjukhuset Linköping: A Fernström, A Cassel, I Göransson, M Gylling, A Jörgensen; Universitetssjukhuset MAS Malmö: G Sterner, A Christensson, P Hjelmstedt, A Nyström; Universitetssjukhuset Örebro: P Sundin, I Samuelsson, M Tidman, M Johansson, M Löfgren Andersson, M Öhman; Vrinnevisjukhuset Norrköping: P Andersson, A Hallberg Karlsson, L Ringstad.

Thailand

Bhumibol Adulyadej (Royal Thai Air Force) Hospital, Bangkok: A Chittinandana, W Chailimpamontree, P Gojaseni, R Singprasert; King Chulalongkorn Memorial Hospital, Bangkok: K Tungsanga, W Amphun, P Intim, T Kanjanabuch, D Poowarattanakul, C Treratha, P Wongvan; Maharaj Nakorn Chiang Mai Hospital: V Ophascharoensuk, S Jittikanont, T Suriya; Rajavithi Hospital: U Krairittichai, P Indrasthitya; Ramathibodi Hospital, Bangkok: V Sumethkul, A Ingsathit, J Jansomwong, K Lertchalorarn, V Phachiyanukul, T Phiromkit, S Saengsri; Siriraj Hospital, Bangkok: K Vareesangthip, R Chawanasuntorapoj, K Kiattisunthorn, R Larpkitkachorn.

UK

Aberdeen Royal Infirmary: J Webster, J Henderson; Addenbrooke's Hospital, Cambridge: D Jayne, J Hollis, K Townsend; Antrim Hospital: C Harron, N Bleakley, N Hanley; Basildon Hospital: S Morgan, L Brittney; Belfast City Hospital: H Brown, P Maxwell, N Bleakley, N Hanley, H Murtagh; Birmingham Heartlands: M Thomas, E Burke, M Carmody, G Cox, J Dasgin; Broomfield Hospital: G Ali, L Whitehouse, V Williams; Charing Cross and Hammersmith Hospital: E Brown, P Maxwell, G Dlelana, A Esson, S Fagerbrink, F Marshall, B Mazibuko, C Nelson, E Russell, R Williams; Churchill Hospital, Oxford: P Altmann, C McNichols-Thomas, K Parsons; Crosshouse Hospital, Kilmarnock: M MacGregor, J McGowan; Cumberland Infirmary, Carlisle: P Mead, K Gilbanks, M Sanderson; Derby City General Hospital: R Fluck, G Chandler, L Hulme, J Smith; Derriford Hospital, Plymouth: Y Tse, C West; Dorset County Hospital: J Taylor, S Breakspear, B Burgess; Dumfries and Galloway Royal Infirmary: C Isles, J Bell, J Duignan, J Gorman; Edinburgh Royal
Infirmary: C Swainson, C Beveridge, A Cairns, C Johnston, D Miller, F Paterson, L Smith; Glan Clwyd Hospital: M Kumwenda, R Glover; Glasgow Western Infirmary: C Geddes, C Gemmell, I Grieve, C Johnston, E Matthews, B McLaren, B Meyer, A Spiers; Gloucestershire Royal Hospital: R Banks, P Apperley, T Patterson, H Paynter; Guys Hospital, London: J Scoble, D Thom, J Watkins; Hope Hospital, Salford: P Kalra, S Gowland, L Haydock, I Smart; Hull Royal Infirmary: S Bhandari, D Lewis, P Gillett, K James, R Lewis, H Melville, A Tamimi; Ipswich Hospital: P Williams, K Brown, T Heath, S Small; James Cook University Hospital, Middlesborough: A Paterson, N Gibson, C Laven, R Reaich, T Wilson; King's College Hospital, London: H Cairns, K Casley-Ready; Leicester General Hospital: G Warwick, B Fentum, J James, T Kumar, R Marshall, F Ratcliffe, A Shenton; Lister Hospital, Stevenage: P Warwicker, M Bowser, C Mumford; Manchester Royal Infirmary: S Mitra, S Johnson, J Morgan; Middlesex Hospital: R Woolfson, R Yang; Morriston Hospital, Swansea: A Williams, K Richards, M Thomas, A Turner; New Cross Hospital, Wolverhampton: J Odum, P Rylance, A Smallwood, J Ward; Ninewells Hospital, Dundee: I Henderson, M McMahon; Norfolk and Norwich University Hospital: C Ross, M Burrows, J Morais, S Rajan; North Middlesex University Hospital: H Tindall, C Barrett, F Kelly; Northern General Hospital, Sheffield: M El-Nahas, J Bartholomew, L Edwards, F Okhuoya; Nottingham City Hospital: C Bebb, M Cassidy, S Brand, M Quashie-Howard, C Taggart; Princess Royal Hospital, Telford: N Capps, D Donaldson, L Tonks; Queen Alexandra Hospital, Portsmouth: J Mason, S Powell, L Watkins; Queen Elizabeth Hospital, Birmingham: S Ball, M Dutton, L Fifer, F McGlynn; Queen Margaret Hospital, Dunfermline: M Wood, D Jenkins, N Allan, K Chalmers; Queen's Hospital, Romford: I Fahal, H Elhag-Ali, J King; Raigmore Hospital: R Peel, L Potts, I Logie, F McGhie; Royal Berkshire Hospital: R Naik, J King; Royal Cornwall Hospital: R Parry, K Andain, S Durkin; Royal Devon and Exeter Hospital: R D'Souza, D Harrison; Royal Free Hospital, London: D Wheeler, J Cooke, R Kinyanjui, S Smith; Royal Liverpool Hospital: J Harper, K Algate, M McCarthy, D Van Eker; Royal London Hospital: R Thuraisingham, M Chinodya, V Deelchand, R Garcia, R Ngango, C Rolfe, K Williams; Royal Preston Hospital: L Solomon, T Heap, P MacDowall, L Saunderson Smith; Royal Sussex County Hospital: A MacDiarmaid-Gordon, W Harman, H Smithson; Sandwell General Hospital, West Bromwich: D Robertson, B Gammon, D O'Grady, C Verow; Southampton General Hospital: M Rogerson, L Berry, C Gough, E Hayward, C Jones, T Payne, L Rowe, C Sibley, J Szymanski; Southend Hospital: M Almond, M Farrell; Southmead Hospital: C Tomson, L Bourton, C Bromwich, H Corderoy, S Dawson, S Mason; St George's Hospital, London: D Oliveira, R Ramkhelawon, J Tuazon; St Helier Hospital, Carshalton: P Andrews, K Archer, A Moore, G Thomas, C Velazquez; St Luke's Hospital, 
Bradford: R Mumtaz, R Roberts, F Farquhar, J Ott; Sunderland Royal Hospital: S Fenwick, A Callaway, D Donaldson; Tyrone County Hospital: P Garrett, L Dees, U McDonagh; University Hospital of North Staffordshire: J Wessels, S Garner, K James; Walsgrave Hospital: D Zehnder, N Aldridge, C Dyer, M Gomez, S Hewins, K McCarthy, J Rush; Worcestershire Royal Hospital: S Spencer, K Brown, M Harvey, H Mills; Wrexham Maelor Hospital: P Drew, M Henry, S Wilberforce; York Hospital: D Worth, Z Adair, J Hartley; Ysbyty Gwynedd: M Jibani, D Jones.

USA

DaVita Clinical Research/Hennepin County Medical Center, Minneapolis: S Swan, T Shamp, H Alcorn Jr, J Bookey, C Cannon, K Jarvis, C Muesing, M Murphy, H Muster, M Planting, C Strand; Duke University Medical Center, Durham: J Middleton, K Gitter, N Mace, D Schumm; Harlem Hospital Center/Columbia University: V Pogue, B Alimohammadi, H Anderson, P Arora, L Herbert, J Cheng, D Dowie, S Mohan, G Peters; Heart Institute of Spokane: K Tuttle, S Albritton, R Benedetti, S Joshi, B Lund, L Shuler; Innovative Research of West Florida, Inc: M Trevino, K Mai, T Osborn; Johns Hopkins University Hospital, Baltimore: R Parekh, J Eustace, G Novak, S Patterson; Kansas City VA Medical Center-1: C Lindsey, T Hill, M Liston; Kansas City VA Medical Center-2: T Wiegmann, A Nagaria, C Hurd, A Hurst, E Omoscharka, S Parks, G Peters, V Price, D Schouten; Kelsey-Seybold Research Foundation, Houston: H Rashid, K Birtcher, J Cantu, S Johnson, C Tait, W Taun; Kidney Associates, PLLC, Houston: S Fadem, D Das, U Khosla, C Brown, T Brown, J Buquing, H Cromwell, N Dickson, B Najimipour, J Robeson, W Tabibi; Medical College of Georgia: L Mulloy, K Bailey, B Burton, P Fall, M Jagadeesan, W Paulson, H Szerlip, J White; Meharry Medical College, Nashville: M Faulkner, O Adeleye, D Boatright, D Mensah, U Nwankwo, L Crutcher, C Cummings, M Floyd, B Putatunda, J Ross, V Sanford; Oklahoma City VA Medical Center: U Thadani, L Haragsim, B Parker, L Rogan, M Thresher, J Turner; Rhode Island Hospital: L Dworkin, D Mignano, A O'Mara, D Shemin; Rush University Medical Center, Chicago: G Bakris, E Basta, D Chua, G Neri, I Ahmed, W Elliott, L Fondren, N Hasabou, N Khosla, A Mazin, J Riehle; Salem VA Medical Center: C Kovesdy, J Mendoza, S Ahmadzadeh, A Iranmanesh, M Lewis, J Lu; San Juan VAMC: J Benabe, E Gonzalez-Melendez, B Padilla,
J Serrano; St Mary's Duluth Clinic: T Russ, L Athmann, L Funke, P Larson, D Roach, B Salveson; University of Maryland, Division of Nephrology: J Nogueira, D Hanes, M Hise, P Light, E Copland, J Fink, M Hakim, K Hough, S McMinn, M Weir, C Young; University of Massachusetts Medical Center: G Kershaw, I Hill, B White; University of Nebraska Medical Center: T Plumb, M Florescu, G Groggel, M Martin, V Rao; University of North Carolina: C DenuCiocca, C Candiani, J Cooper, B Gordon, M Joy, M Kiser, C Lambeth; University of Pennsylvania: S Rosas, P Cochetti, J Robinson, K Schankel, H Teng; University of Vermont/ Fletcher Allen Health Care: W Weise, A Geneidy, P Murray, R Solomon, D de Waal, S LaPointe, A Schoenknecht; USC/ Keck School of Medicine, Los Angeles: V Campese, M Habashy, R Ananthakrisna, D Bedwani, U Fazli, M Fetrat, Q Frampton, B Kaldas, V Kazarian, L Pitts, A Sadeghi, N Yeasmin; VA Ann Arbor Healthcare System: E Young, R Fissell, K Belanger, N Ricci; VA Boston Healthcare System, Jamaica Plain Campus: W Farwell, T Bowman, R Dhingra, A Pesenson, J Ambrosino, S Chittamooru, J Kaufman, M Ramos; VA Southern Nevada Healthcare System (VASNHS): C Yap, S Nakhle, L Aligaen, D Duren, B Laine, S Moore, H Tuazon; Washington University School of Medicine: D Coyne, J Audrain, B Bryant, S Dombek, S Freeman, P Klein; Western New England Renal \& Transplant Associates (WNERTA), Springfield: M Germain, A Berkowitz, A Bokhari, G Braden, A Diaz, B Greco, J Mulhern, M O'Shea, A Poindexter, D Poppel, M Ryan, S Sweet, J Ye; Wm. Jennings Bryan Dorn VA Medical Center, Columbia: J Osterman, T Lin, B Mays, A Rizvi, C Sonnier, C Twining, S Wang, M Hix, J Schenck.

\section{Supplementary References}

28. Study of Heart and Renal Protection (SHARP) Final Protocol (version 5: 12th July 2005). Available at: http://www.sharpinfo.org/.

29. Peto R, Pike MC, Armitage $P$, et al. Design and analysis of randomised clinical trials requiring prolonged observation of each patient. Part 1 : Introduction and design. Br J Cancer 1976;34:585-612.

30. Peto R, Pike MC, Armitage $P$, et al. Design and analysis of randomised clinical trials requiring prolonged observation of each patient. Part 2: Analysis and examples. Br J Cancer 1977;35:1-39.

31. Collins R, MacMahon S. Reliable assessment of the effects of treatment on mortality and major morbidity, I: clinical trials. Lancet 2001;357:373-80.

32. Hochberg Y. A sharper Bonferroni procedure for multiple tests of significance. Biometrika 1988;75:800-2. 